\begin{tabular}{|c|c|c|c|}
\hline KULTURA & $\begin{array}{l}\text { POLSKA } \\
\text { KOMITET } \\
\text { INSTYTU }\end{array}$ & $\begin{array}{l}\text { KADEMIANAUK } \\
\text { OCJOLOGII } \\
\text { STUDIÓW POLITYCZNYCH }\end{array}$ & ISSN 0023-5172 \\
\hline SPOLECZENSTWO & 2009, nr 1 & POZA UTARTYM SZLAKIEM & \\
\hline
\end{tabular}

AGNIESZKA FIGIEL

Uniwersytet im. Adama Mickiewicza

\title{
GŁUSI I JĘZYK MIGOWY — SPÓR O JĘZYK I KULTURĘ
}

Mówimy, rozmawiamy, piszemy i czytamy, wymieniamy informacje, przekazujemy wiadomości, opowiadamy, sygnalizujemy — ludzkie interakcje w mniejszym lub większym zakresie są związane $z$ komunikowaniem się. Ludzie porozumiewają się w rozmaity sposób, za pośrednictwem mowy, pisma, gestów czy obrazów, ale każdy z tych sposobów przekazywania informacji nieodmiennie związany jest $z$ językiem. W ten sposób jakakolwiek analiza zjawiska komunikowania się zostaje uwikłana $\mathrm{w}$ rozpatrywanie zależności między tym, co mówione, pisane, pokazywane, a językiem — narzędziem, medium, dzięki któremu owo komunikowanie jest możliwe. Co więcej, nie można zignorować wiedzy o tym, że język to fakt społeczny, istotny element kultury.

„Kiedy mówię, nie jestem sam. Są ze mną tradycje utrwalone w języku, które sprawiają, ze każdy, kto go używa, od razu sytuuje się w roli członka pewnej społeczności [...] Ale kiedy mówię, nie jestem sam, przede wszystkim dlatego, że zawsze zwracam się do drugiej osoby [...]" - to pierwsze zdania wstępu, jaki Michał Głowiński napisał do książki pt. Język $i$ społeczeństwo, poświęconej językowym aspektom życia społecznego i - to wcale nie jest pleonazm - społecznym aspektom zjawisk językowych. Ten krótki cytat najpełniej oddaje związki między językiem a społeczeństwem, bo zwraca uwagę, że akt mówienia, a nawet szerzej — posługiwania się językiem, nie jest możliwy bez uczestniczenia we wspólnocie, czy to pojmowanej jako byt realny, czy też wspólnocie wyobrażonej, symbolicznej. W kolejnych zdaniach Głowiński precyzuje, że posługując się językiem, jednostka musi odwoływać się do innych, czynić kogoś adresatem swoich komunikatów, bo nawet jeśli nadawca mówi sam do siebie, to i tak przypisuje sobie wówczas rolę „drugiego”, rolę słuchacza. Co więcej, korzystanie z języka to nieuchronne odwoływanie się do kultury, owego społecznie ukształtowanego zasobu wiedzy i rezerwuaru wytycznych, wedle których należy żyć (Głowiński 1980, s. 5).

Adres do korespondencji: afigiel@amu.edu.pl. 
Język jest faktem społecznym, bo przede wszystkim czyni świat społeczny możliwym, jest podstawą więzi wspólnotowej, poczucia intersubiektywności i bycia-w-świecie. Pełne wyrażanie siebie przez jednostkę możliwe jest tylko za pomocą języka - to on nadaje kształt myślom, pozwala formułować poglądy. Albowiem „tak podkreślane na przykład w obrębie symbolicznego interakcjonizmu mechanizmy wewnętrznej konwersacji stanowiące istotę funkcjonowania osobowości [...] to w zasadzie nie więcej niż zjawiska językowe" (Ziółkowski 1981, s. 224-225). Sytuacja: „wiem, ale nie potrafię tego wyrazić słowami", jest dla jednostki niewygodna, bo uświadamia jej własną poznawczą bezradność - zarówno wobec własnego ,ja”, jak i wobec otaczającego ją świata. Rzeczywistość może być bowiem o tyle oswojona, o ile można ją nazwać i zdefiniować jej granice. Stąd też niepohamowana skłonność ludzi do nazywania tego, co ich otacza. Rzecz, istota żywa czy sytuacja bez nazwy nie może istnieć, jest „obca”, nie ma swojego symbolicznego odniesienia, które pozwala ją zobrazować, przypomnieć, wyobrazić sobie. Dlatego „posiadłszy instynkt nazywania, ludzie już zawsze chcą nazywać rzeczy. Lubią nazywanie dla samego nazywania” (Aitchison 2002, s. 129). Język pomaga więc „zapanować" nad światem, uczynić rzeczywistość przynajmniej pozornie kontrolowalną.

Ponadto za pomocą języka jednostka „opuszcza” świat własnych odczuć i myśli, i „przechodzi” do świata współdzielonego z innymi. Język pozwala włączyć się w obręb szerszych grup, których dziedzictwo to nie tylko dorobek współcześnie żyjących, ale i kulturowa spuścizna przodków. W owych społecznościach język może pełnić kilka istotnych funkcji (Ziółkowski 1981, s. 225 , 1998 , s. 371 ; Sztompka 2002, s. 291). Po pierwsze, stanowi podstawę socjalizacji - jest więc czynnikiem wprowadzającym jednostkę $\mathrm{w}$ świat społeczny. Po wtóre, język jest tym, co czyni możliwym istnienie abstrakcji, uogólnień i symboli. Po trzecie, bez języka nie mogłoby zaistnieć zjawisko rozumienia drugiego człowieka, cały ten skomplikowany proces stawiania siebie $\mathrm{w}$ roli Innego, budowania intersubiektywnego świata przekonań. Po czwarte, język umożliwia komunikację międzyludzką, a co za tym idzie - realizację przez członków społeczności wspólnych działań. Po piąte, stanowi czynnik wytwarzający wewnętrzną solidarność grupową - wspólnota języka oznacza wspólnotę świata i wartości, daje poczucie my, bo, jak zauważył Edward Sapir: "język jest wielką siłą konsolidującą" (Sapir 1978, s. 45). I wreszcie na koniec, język jest systemem zapisu wiedzy, rejestracji zdarzeń, nośnikiem tradycji, tym samym stanowi swoistego rodzaju „kulturowy depozyt".

Przedmiotem poniższych rozważań jest jeden ze sposobów komunikowania się, a mianowicie język migowy oraz konsekwencje, jakie dla pewnych społeczności ma fakt posługiwania się nim. Języki migowe są stosowane przez ludzi, dla których efektywne korzystanie $z$ języka fonicznego jest $z$ różnych względów niemożliwe - dotyczy to przede wszystkim osób z ograniczonymi zdol- 
nościami narządu słuchu ${ }^{1}$. Chciałabym zastanowić się najpierw nad miejscem języka migowego pośród innych sposobów komunikowania się, nad teoretycznymi implikacjami uznania języka migowego za pełnoprawny język ludzki oraz całkiem nienaukowym sporem o to, czy i jakim językiem migowym powinny posługiwać się osoby głuche. Ponadto, w drugiej części artykułu, zwrócę uwagę na kulturowe implikacje korzystania $z$ języka migowego, a zwłaszcza na potencjał języka w kreowaniu i utrzymywaniu kulturowej tożsamości. Chciałabym tylko zaznaczyć, że niniejszy tekst nie aspiruje do miana całościowej monografii społeczności głuchych użytkowników języka migowego, a stanowić ma próbę wskazania interesujących mnie aspektów funkcjonowania języka migowego tuż obok języków fonicznych.

\section{JĘZYK - MOWA — GESTY — PISMO, CZYLI SPÓR O JĘZYK MIGOWY}

$\mathrm{Na}$ początku warto zauważyć, że rozpatrując kwestie związane z językiem, tak naprawdę bierze się pod uwagę całą klasę zjawisk, takich jak "język", „znak”, „symbol”, „mowa”, „mówienie”, „komunikowanie”, „pismo”, „tekst”. Pojęcia te pozostają we wzajemnych związkach znaczeniowych, dookreślając, uzupełniając bądź definiując się wzajemnie. Rozpatrywanie owych relacji nie jest proste, aczkolwiek użyteczne poznawczo — pozwala bowiem na jak najpełniejszą charakterystykę tego, co ogólnie można określić jako zjawiska językowe. Ponieważ przedmiotem tych rozważań jest język migowy, chciałabym zwrócić szczególną uwagę na semantyczne związki między pojęciami „język”, „mowa”, „gesty” i „pismo”, wskazując te kwestie, które w moim przekonaniu wymagają teoretycznej reinterpretacji.

Język powszechnie pojmowany jest jako system — znaków lub symboli. Niekiedy, tak jak w definicji sformułowanej przez Piotra Sztompkę (2004, s. 289), akcentuje się ponadto jego społeczny charakter: „język to skomplikowany system powiązanych ze sobą symboli, będący własnością określonej społeczności”. O ile językowi nie odmawia się „systemowości”, czyli pewnej struktury, zbioru reguł formujących, to o tyle nie ma już pełnej zgody co do tego, co na ową strukturę się składa, co jest przez wspomniane reguły wiązane w większe całości: znaki czy symbole. Ta rozbieżność wiąże się z niesprecyzowanym w naukach społecznych sposobem definiowania znaków i symboli, co więcej — niejednokrotnie zdarza się, że pojęcia te stosowane są zamiennie.

\footnotetext{
${ }^{1}$ Język migowy w swojej uproszczonej formie jest stosowany tam, gdzie komunikacja werbalna nie jest skuteczna, na przykład w środowisku, w którym panuje duży hałas - operatorzy maszyn w hałaśliwych halach fabrycznych wypracowują sobie własny system porozumienia się za pomocą gestów. Innym przykładem użycia języka migowego jest próba komunikowania się z niemowlętami, które jeszcze nie opanowały mowy — tzw. bobomigi (sing2baby) wykorzystują znaki języka migowego niesłyszących i pozwalają na skuteczną komunikację z dziećmi kilkumiesięcznymi. Komunikacja gestowa jest w kolejnych latach, wraz z rozwojem dziecka, powoli zastępowana komunikacją werbalną (na podstawie: http://www.migowy.pl [19.05.2008]).
} 
Na przykład dla Schütza znaki to „przedmioty lub sposoby zachowania celowo stworzone dla przekazania innym jakiejś treści, jakiegoś przesłania [...] najbardziej złożonym systemem znaków jest język" (Sztompka 2006, s. 103), symbole zaś to znaki drugiego stopnia, metaznaki czy, inaczej rzecz ujmując: znaki znaków (tamże). Język (jako zjawisko bardzo ogólne) w tym ujęciu jest więc systemem znaków, a język nauki (a więc szczegółowe zastosowanie języka) jest systemem symboli — bo odnosi się do tego, co już jest znaczące.

$\mathrm{Z}$ kolei Charles Pierce znak uznawał za kategorię bardzo szeroką, w ramach której wyróżnił kilka podzbiorów. Znaki-ikony charakteryzują się istotnym podobieństwem do tego, co oznaczają — w tym sensie zdjęcie kota jest znakiem-ikoną zwierzęcia, jakim jest kot. Znaki-indeksy wiąże z tym, co oznaczają, pewna prawidłowa, typowa, powtarzalna zależność, na przykład przyrodnicza (błyskawica jest znakiem-indeksem burzy), społeczna, psychologiczna, ekonomiczna czy kulturowa. Z kolei znaki-symbole są całkowicie umowne, ich znaczenie określane jest konwencją kulturową (Sztompka 2006, s. 82). Język w tym ujęciu byłby systemem właśnie znaków-symboli, gdyż każdy ze znaków (czyli słowo) nie ma swojej bezpośredniej reprezentacji w rzeczywistości, lecz jedynie kulturowo nadane znaczenie.

Rozróżnienie poczynione przez Pierce'a doskonalej niż to zaproponowane przez Schütza akcentuje tę cechę języka, co do której nie ma wątpliwości: jego symbolizm. Ale samo uznanie języka za system symboli nie wyczerpuje jeszcze jego charakterystyki. Ludzie posługują się bowiem wieloma symbolicznymi systemami, jak znaki drogowe czy piktogramy. Czynione próby wyodrębnienia języka ludzkiego spośród innych systemów znaków sprawiły, iż za jego cechę dystynktywną uznano to, że jest oparty na znakach dźwiękowych. Edward Sapir (2003, s. 47) zauważa, że język jest „systemem symboli fonetycznych, który służy wyrażaniu dających się przekazać myśli i uczuć”. Marek Ziółkowski z kolei zwraca uwagę na dwie, zakresowo różne definicje pojęcia „język", z których szersza traktuje język jako ogólny system komunikowania; natomiast węższa odnosi się do „ludzkiego języka naturalnego, czyli właściwego jedynie człowiekowi systemu komunikowania opartego na znakach (symbolach) dźwiękowych" (Ziółkowski 1998, s. 371). W tym miejscu zatem do zbioru rozpatrywanych pojęć należy dołączyć kolejne: „mowa” i „mówienie”.

Namysł nad związkami języka i mowy bierze swój początek w rozważaniach nad istotą człowieczeństwa, w próbie odpowiedzi na pytanie, czym różni się człowiek od zwierząt i gdzie przebiega granica między naturą a kulturą. Richard Leakey w Pochodzeniu człowieka (2003, s. 26) wyjaśnia ten proces w następujący sposób:

„[...] w dziełach antropologicznych przez wiele lat uwagę poświęcano manifestacjom zachowań uważanych za wyłącznie ludzkie. To znaczy umiejętności produkcji narzędzi, posługiwania się symbolami, rozpoznawania swojego odbicia w lustrze i, oczywiście, zdolności posługiwania się mową. Od lat sześćdziesiątych ten przypisany wyłącznie człowiekowi monopol na zachowania począł 
się kruszyć, okazało się bowiem, że małpy też mogą wytwarzać i posługiwać się narzędziami, że też używają symboli i też rozpoznają się w lustrze. $\mathrm{Z}$ monopolu pozostał tylko język mówiony, tak więc językoznawcy uznali go za jedynego obrońcę ludzkiej wyjątkowości [...]".

Jednym z czołowych orędowników poglądu, by bastionem człowieczeństwa uczynić właśnie język mówiony, jest antropolog Claude Lévi-Strauss, który w rozmowie z Georgesem Charbonnierem wyjaśniał, że ,jednym z moich zasadniczych celów było zawsze przeprowadzenie linii demarkacyjnej pomiędzy kulturą i naturą nie ze względu na obecność narzędzi, lecz języka artykułowanego. To tam rzeczywiście dokonuje się skok" (Lévi-Strauss 2003, s. 22). W ten sposób pojawienie się mowy uznano za wskaźnik człowieczeństwa, za ową granicę oddzielającą ludzkość od świata natury, świata zwierząt.

Język mówiony został na trwale wpisany w zestaw cech typowo ludzkich, co w konsekwencji prowadziło do następującej, nie zawsze uświadamianej i wyrażanej wprost konstatacji: brak języka mówionego lub też nieposługiwanie się nim to zaprzeczenie bycia człowiekiem lub - w łagodniejszej formie oznaka ułomności. Owo przekonanie, w przypadku osób niesłyszących, a co za tym idzie - nieposługujących się językiem mówionym, stało się podstawą stereotypu, jakoby głuchota była równoznaczna $z$ niedorozwojem intelektualnym. Osoba głucha jako „niemowa” traktowana jest wówczas na równi z tymi, którzy mowy nie opanowali ze względu na upośledzenie umysłowe. Obie grupy są więc inne, wykluczone $z$ powszechnego systemu porozumiewania się, „wypchnięte" na margines komunikującego się mową społeczeństwa. W ten sposób głuchy staje się Obcym, jak dziecko, cudzoziemiec czy upośledzony - każda $z$ tych osób nie posługuje się językiem większości, nie „mówi”, nie jest w stanie uczestniczyć w komunikacyjnej wspólnocie. Do wątku obcości, inności osób głuchych jeszcze powrócę.

Warto zaznaczyć, że wspomniane wyżej utożsamienie człowieczeństwa z mówieniem sprawiło, iż w językoznawstwie i naukach społecznych pojęcia "język" i "mowa” zaczęto traktować może nie jako synonimiczne, ale na pewno bliskie znaczeniowo. Co więcej, to „mowa” stała się pojęciem ogólniejszym, tak jakby to ono właśnie najmocniej podkreślało fakt, że przedmiotem rozważań jest język ludzki. Niemała w tym zasługa francuskiego lingwisty Ferdinanda de Saussure'a, który zaproponował, by „w obrębie szeroko rozumianej mowy (langage), wyodrębnić należy język (system językowy, język-kod, czyli langue) [...] oraz indywidualne akty mówienia (parole)" (Ziółkowski 1998, s. 371). De Saussure pierwszeństwo i największy znaczeniowy zakres przyznaje więc mowie, gdyż „[...] langage odnosi się do mowy pojętej jako zdolność mówienia, bądź rozumianej jako zbiór wszystkich zjawisk związanych z mówieniem" (Piotrowski, Ziółkowski 1976, s. 71).

Utożsamienie języka ludzkiego $z$ mową miało także inne konsekwencje, a mianowicie spowodowało deprecjację odmiennych sposobów komunikowania się, nie wokalnych, lecz wykorzystujących kanał wzrokowy, czyli gestów 
i obrazów. W tym miejscu chciałabym krótko rozważyć relacje między pojęciami „język”, „mowa” i „gest”, co jest o tyle istotne, że na systemie gestów oparty jest przedmiot moich dociekań: język migowy.

W naukach społecznych gesty pojmowane są dość szeroko - jako wszelkie ruchy rąk, mimika i ruch całego ciała $\mathrm{w}$ przestrzeni ${ }^{2}$. Analiza związków między mową a gestami nieodmiennie prowadzi ku pytaniu, co jest pierwotne, a co wtórne? Który ze sposobów komunikacji uznać za ważniejszy i dlaczego? Jean Jacques Rousseau, rozważając to, jak ludzie porozumiewają się ze sobą, zauważa, że chodzi przede wszystkim o oddziaływanie na dwa zmysły: wzrok i słuch, co prowadzi do wykształcenia dwóch języków: języka gestu i języka głosu. Oba są równie przyrodzone człowiekowi, aczkolwiek pierwszy z nich jest bliżej stanu natury niż drugi. Według Rousseau, gesty są bardziej bezpośrednie, mniej podlegają umowom i konwencjom, nie są tak ulotne jak dźwięki. Gesty ponadto pozostają bliżej ciała ludzkiego w tym sensie, że mocniej angażują owo ciało w swoje powstawanie (por. Rousseau 1956, 2001). Jacques Derrida, analizując koncepcję Rousseau, zauważa jednak, że owa „naturalność” języka gestów w efekcie stanowi jednak jego wadę. Posługiwanie się gestami wymaga patrzenia, koncentrowania uwagi odbiorcy na samej osobie nadawcy, co ogranicza możliwość komunikowania się do linii zasięgu wzroku. Z kolei mowa jest o wiele bardziej przestrzenna, bo pozwala na przekazywanie informacji bez konieczności bezpośredniego kontaktu nadawcy z odbiorca. Jak pisał Derrida (2005, s. 485), „mowa przykuwa uwagę, to, co widzialne, jej wymaga”.

Brak konieczności kontaktu wzrokowego przy posługiwaniu się językiem mówionym sprawił, że mowa jest o wiele bardziej niż gesty wszechogarniająca i wszechobecna, bo łatwiej „można zamknąć oczy lub odwrócić wzrok, niż powstrzymać się od słuchania" (Derrida 2005, s. 485). Owa większa uniwersalność mowy spowodowała jej dominację nad językiem gestów. Według Rossueau, proces ten jest nieodłącznie związany z przechodzeniem człowieka od stany natury do kultury - pierwotny, ikoniczny język gestów zostaje zastąpiony symbolicznym językiem mówionym. Gesty od tej pory przywoływane są wówczas, gdy trzeba wzmocnić mówiony komunikat, nadać mu szczególne znaczenie i bezpośredni, wizualny, ikoniczny rys. Gesty stanowią w takim ujęciu reminiscencję stanu natury, przypomnienie tego, co w człowieku pierwotne. Poza tym kulturowo oswojone gesty stały się częścią rytuałów, mniej lub bardziej skomplikowanych sekwencji zachowań, które mają na celu potwierdzanie reguł życia społecznego, konstruowanie i rekonstruowanie społecznej struktury.

2 Ralph H. Turner (2006, s. 273), opisując założenia koncepcji symbolicznego interakcjonizmu, definiuje "gest” jeszcze szerzej, bo jako „każde zachowanie, któremu aktor lub obserwator może przypisać jakieś znaczenie". Tak szeroka definicja gestu oraz nadawanie gestom owego specjalnego miejsca $\mathrm{w}$ procesie komunikacji są charakterystyczne dla symbolicznego interakcjonizmu i etnometodologii. 
Analizując relacje między tym, co mówione, a tym, co pokazywane, należy podkreślić, że wspomniana wyżej dominacja mowy sprawiła, iż w przypadku języków dźwiękowych gesty stanowią tło, drugorzędny ciąg symboli, jednakże do pewnego stopnia autonomiczny i rządzący się własnymi prawami. Jak pisał Anthony Giddens (2006, s. 104): „codzienna interakcja polega na subtelnej relacji między tym, co wyrażamy słowami, a tym, co przekazujemy za pośrednictwem licznych form komunikacji niewerbalnej - wymiany informacji i komunikacji sensów przez wyraz twarzy, gesty i ruchy ciała". Gesty w interakcji (wraz z mimiką i ruchem ciała) rozpatrywane są przez jednostki w kategoriach odczytywania emocji, orzekania o prawdzie lub fałszu wypowiedzi interlokutora. Stąd dzielenie gestów na te, którymi manipulować się da, i te, które manipulacji się nie poddają. Stąd również wszelkie poradniki dotyczące komunikacji niewerbalnej, tego, jak manipulować gestami, by w rezultacie skutecznie manipulować rozmówcą.

Znaczenie gestów w interakcjach jest jednakże daleko większe niż tylko świadczenie o prawdzie czy kłamstwie, niż bycie elementem gry z odbiorcą.

„[ludzie] gdy mówią i przywołują nazwy rzeczy czy stanów rzeczy, często próbują je jeszcze pokazać. Co jednak ciekawsze, nie czynią tego wtedy, gdy nazwa posiada realnego reprezentanta rzeczy (nie pokazują więc piłki, konia czy lampy), ale wtedy, gdy sądzą, że samo jej przywołanie może nie dostarczyć partnerowi komunikacji wystarczającej informacji o mentalnym wyobrażeniu tej rzeczy czy też «stanu tej rzeczy»" (Antas 2006, s. 183).

Gesty, według Jolanty Antas, nie są bowiem kopiami rzeczywistości, ale znakami jej mentalnego przetworzenia. Innymi słowy, ubogacając wypowiedź gestami, „dopowiadamy” to, co jest niejako poza pierwszą warstwą symboliczną, czyli słowami. Gesty nie tylko odwołują się do słów, ale sięgają głębiej, do warstwy drugiej, jaką są nasze myśli, wyobrażenia, konstrukty mentalne. Na przykład słowa „iść na skróty” mogą zostać zobrazowane przez gest, w którym dłonie pokazujące wąską ścieżkę, jakby przecinającą szerszą drogę; z kolei gestem obrazującym słowa „to nieprawdopodobne” może być ułożenie dłoni tak, jakby próbowały coś pochwycić, zmagały się z czymś nieporęcznym, wymykającym się spod kontroli (Antas 2006, s. 196-199).

Jednak mimo że gesty mogą być interpretowane jako znaki mentalnego przetworzenia rzeczywistości, ich pozycja względem języka fonicznego nie zmienia się: wciąż stanowią tylko "symboliczne” tło, uzupełnienie komunikatów werbalnych. Co więcej, nieobecność słów czyniłaby ten rodzaj gestów niezrozumiałymi, a proces odwrotny - pozbawienie mowy jej gestowego towarzystwa nie zubaża zbytnio komunikatu ani nie czyni go nieczytelnym. W efekcie po raz kolejny należy skonstatować, że w konfrontacji z gestami język mówiony wydaje się znacznie efektywniejszym kanałem komunikacyjnym. Sytuacja zmienia się dopiero wtedy, gdy to właśnie gesty uczynimy głównym kanałem przekazu, gdy to gestom zostanie oddana „władza” nad komunikacją. Nie tyle czasowe, ile trwałe odseparowanie gestów od mowy powoduje, że gesty przestają stanowić 
tylko tło, ale same nabierają cech znaków dźwiękowych. Pozornie oderwane od siebie, do tej pory znaczące tylko w określonych kontekstach, naturalne, bezpośrednie i ikoniczne, wedle ujęcia Rousseau, gesty układają się w skomplikowany system symboli — w język migowy.

Języki migowe nie są prostym odzwierciedleniem narodowych języków fonicznych ${ }^{3}$, przełożeniem słów na gesty. Według językoznawców, struktura języka migowego - podobnie jak języków dźwiękowych — składa się z dwóch poziomów (zob. Szczepankowski 1997, 2000; Tomaszewski 2007). Pierwszym (i podstawowym) są znaki - czyli gesty - które odpowiadają jednemu bądź kilku słowom języka fonicznego. Znaków takich, w zależności od języka, może być od kilku do kilkunastu tysięcy. Około 1/3 ich liczby stanowią znaki ikoniczne, które naśladują kształt danego przedmiotu, czy ruch wykonywany w danej sytuacji. Ponadto istnieją tzw. klasyfikatory, czyli znaki niesamodzielne, stosowane do oznaczenia czasu, stanu emocjonalnego itp. Repertuar gestów jest uzupełniony o znaki daktylograficzne, czyli alfabet palcowy (gdzie jeden gest to jedna litera) i znaki oznaczające liczby. Wszystkie znaki gestowe języka migowego można podzielić ponadto na proste i złożone, analogicznie jak w przypadku języków fonicznych. W językach dźwiękowych mamy do czynienia $z$ fonemami i morfemami, natomiast $\mathrm{w}$ przypadku języka migowego „z elementarnych "fonemów» wizualnych nie mających jeszcze znaczenia powstają morfemy w postaci znaków migowych posiadających znaczenie" (Tomaszewski 2007). Ta cecha nazywana jest dwuklasowością i stanowi o wyjątkowości języka ludzkiego wśród innych systemów znaków (por. Piotrowski, Ziółkowski 1976, s. 62-63).

Drugi poziom struktury języka migowego to gramatyka, której występowanie wspólne jest językom dźwiękowym i wizualno-przestrzennym. Jednakże gramatyka języka migowego nie jest prostym odwzorowaniem zasad gramatyki języka fonicznego, na przykład Polski Język Migowy (PJM) w odróżnieniu od dźwiękowego języka polskiego nie ma fleksji gramatycznej, związanej z występowaniem końcówek wyrazów, czyli formantów fleksyjnych (na przykład pyta-ć / pyta-ł / pyta-łam), lecz fleksję przestrzenną - kierunek pokazywania znaku wskazuje na wykonawcę czynności i jej adresata. Ponadto gramatyka języka migowego jest gramatyką pozycyjną, według której najważniejszy jest szyk zdania — to on decyduje o znaczeniu ciągu gestów. Równie ważne są: mimika (która na przykład odpowiada za to, czy migane zdanie jest zdaniem oznajmującym czy pytaniem) oraz ruchy rąk i całego ciała (charakteryzują rodzaje relacji między miganymi znakami, oznaczają także na przykład, czy wypowiedź jest w czasie przeszłym czy przyszłym). Język migowy jest więc językiem wizualno-przestrzennym, bo osoba posługująca się nim do komunikacji wykorzystuje całą

3 Dalej wyjaśniam dokładniej mechanizm powstawania języków migowych, teraz tylko chciałabym zaznaczyć, że nie istnieje jeden naturalny powszechny język migowy, tak jak nie istnieje jeden naturalny powszechny język foniczny — oba typy języków są zróżnicowane etnicznie i kulturowo. 
przestrzeń wokół siebie, a poszczególne elementy tej przestrzeni mają swoje określone znaczenia.

Struktura języka migowego jest wobec tego o wiele bardziej skomplikowana, niżby się na pierwszy rzut oka wydawało, i stanowi zdecydowany argument za tym, by język wizualno-przestrzenny uznać za pełnoprawny język ludzki, równy językom fonicznym. Tak jak języki dźwiękowe, składa się bowiem $z$ dwóch klas znaków (symboli), powiązanych w większe całości zasadami gramatyki. Ponadto funkcjonuje w obrębie określonej społeczności, stanowiąc podstawę podejmowanych w niej interakcji i - co zostanie dalej wykazane - czynnik tworzenia i podtrzymywania kulturowej odrębności. Zanim jednak przejdę do zagadnień związanych z kulturowymi implikacjami funkcjonowania języków migowych, chciałabym rozpatrzyć ostatni z anonsowanych na wstępie „związków pojęciowych", a mianowicie relacje między językiem mówionym/ pokazywanym a pismem.

Na gruncie antropologii przyjmuje się, że tak jak wykształcenie mowy oddzieliło świat człowieka od świata natury, tak pojawienie się i ewolucja pisma odgraniczyły kultury pierwotne od kultur, w których narodziły się literatura, nauka, filozofia. Pismo uniezależniło kulturowy przekaz od siły pamięci ludzkiej, pozwalając na tworzenie narracji wielowątkowych, skomplikowanych, w których wiedza była kumulowana w sposób nieograniczony. Co więcej, pismo zmieniło także sposób zarządzania wiedzą. $Z$ jednej strony zapisana wiedza stała się czymś elitarnym, bo dostępnym tylko tym, którzy posiedli umiejętność czytania. Z drugiej zaś strony, zapisana wiedza została „oderwana” od społeczności, która ją wytworzyła - poznanie nie wiązało się już z koniecznością spotkania z człowiekiem, wystarczyło „spotkanie” z tekstem (Riesman 2003, s. 399). Pismo jako pierwsze pozwoliło na kontakt zapośredniczony, później rolę taką w sposób doskonalszy zaczęły pełnić inne, mniej lub bardziej „piśmienne” media: telewizja i internet.

Pismo wpłynęło także na sam sposób posługiwania się językiem: wymogło uporządkowanie sposobu przekazywania informacji, położyło nacisk na układanie słów zgodnie $z$ zasadami gramatyki, na to by - metaforycznie rzecz ujmując - słowa wiązać w zdania, a zdania zaczynać dużą literą i kończyć kropką. W piśmie język jest ujarzmiony, odkryta zostaje jego struktura. Tekst jawi się ponadto jako coś pewnego i stałego, podczas gdy mowa jest chwilowa, kontekstowa. W potocznej świadomości „zapisać” to utrwalić, a słowa mówione można „rzucić na wiatr”. Poprzez pismo nadawca zostaje „odseparowany" od komunikatu od momentu jego wytworzenia, podczas gdy słowa mówione nieodwołanie związane są z sytuacją ich użycia, z działaniem.

Wymienione wyżej zależności sprawiły, że pismo zyskało miano gwaranta kulturowego awansu danego języka — język, które może zostać zapisany jest językiem trwalszym, „mocniejszym”, dającym możliwość rozwoju wiedzy, a nie tylko służącym do codziennej, nacechowanej utylitaryzmem komunikacji. Co więcej, pismo pozwala usystematyzować, skodyfikować dany język i rządzące 
nim zasady. W ten sposób język zostaje do pewnego stopnia ujednolicony, wykształca się jego powszechnie obowiązująca wersja, wspólna wszystkim posługującym się nim jednostkom. Oczywiście pismo nie sprawia, że giną socjolekty i zamierają gwary — pismo raczej obnaża podstawową strukturę języka, uwidacznia i eksponuje najbardziej pierwotne zasady słowotwórstwa i gramatyki (czyli langue, według koncepcji de Saussure'a), chroniąc tym samym język przed rozmyciem się $\mathrm{w}$ różnorodności jego indywidualnych zastosowań, $\mathrm{w}$ wielości de Saussure'owskich parole.

Odniesienie powyższych rozważań o roli pisma do języka migowego ujawnia kolejne cechy odróżniające go od języków fonicznych. Przede wszystkim społeczności posługujące się językiem migowym nie wykształciły w naturalny sposób odpowiadającego mu pisma. Pismo powstałe na przestrzeni wieków jest bowiem zapisem języka fonicznego, w którym określonym symbolom dźwiękowym przyporządkowano symbole graficzne. Dlatego też struktura pisma odzwierciedla strukturę, słownictwo i gramatykę, języka fonicznego. Osoby posługujące się językiem migowym mają dwie możliwości, by cokolwiek zapisać. Po pierwsze, mogą skorzystać z SignWriting ${ }^{4}$, czyli ze stosunkowo nowego pomysłu na przedstawianie znaków języka migowego w postaci piktogramów. Jego wadą jest jednak mała powszechność oraz to, że składające się nań obrazki niewprawnym w jego użytkowaniu głuchym (ale także osobom słyszącym) mogą się wydać dość nieczytelne i skomplikowane.

Drugim wyjściem, częściej stosowanym przez osoby niesłyszące i efektywniejszym w życiu codziennym, jest poznanie, nauczenie się i wykorzystywanie pisma $\mathrm{w}$ jego standardowej postaci, w której słowom odpowiadają złożone $z$ liter wyrazy. Wbrew pozorom opanowanie umiejętności bezbłędnego pisania nie jest dla osób niesłyszących łatwe. $Z$ jednej strony bowiem język migowy, mimo że nie jest subkodem języka fonicznego (czyli Polski Język Migowy nie jest subkodem fonicznego języka polskiego), na poziomie Fodorowskiego mentalese $^{5}$ odwołuje się do tego samego słownika. Z drugiej zaś strony — foniczny język polski i Polski Język Migowy mają różną strukturę. Polscy głusi my ślą po polsku, podobnie jak ich słyszący rodacy, ale mówią nie w języku polskim, lecz w PJM. Na poziomie pisma, jeżeli nie stosuje się znaków SignWriting, ta odrębność ulega zatarciu. Polscy głusi, podobnie jak inni Polacy, pi s zą w języku polskim. Warto jednak zaznaczyć, że mimo wszystko następuje tu swoisty przekład z jednego języka (mówionego) na drugi (pis any). Odmienność gramatyczna PJM sprawia, że głuchym bardzo często zdarza się popełniać błędy

4 www.signwriting.com

5 Mentalese (lingua mentalis, language of thought) to zaproponowana przez Jerry'ego A. Fodora koncepcja języka myśli. Język ten zawiera w sobie symboliczne odniesienia do rzeczywistości, ale jego zdania nie są zdaniami języka naturalnego. Przełożenie zdań języka myśli na zdania języka naturalnego dokonuje się przez werbalizację (por. Fodor 2001). W tym miejscu, reinterpretując założenia Fodora, można dodać, że w obok werbalizacji możliwa jest również wizualizacja —zdania mentalese przekładane są na zdania języka migowego. 
w odmianie słów oraz strukturze zdań (na przykład „Nie lubię jak ktoś bez moje pytania wypakują w nadziei że dobrze zrobią. Przyjmę pomoc tylko jak ja prosi o pomoc" ${ }^{6}$ ), mają także kłopoty z formułowaniem wypowiedzi na piśmie. Nie jest to jednak oznaka braku kompetencji językowych, ale raczej wyraźna wskazówka, że choć oba języki — i foniczny, i migowy — są językami polskimi, to nieraz zdecydowanie do siebie nie przystają.

Posługiwanie się przez użytkowników języka migowego pismem właściwym dla języka fonicznego ma swoje, mniej lub bardziej uświadamiane, konsekwencje. Po pierwsze, pismo może stanowić (i najczęściej stanowi) pomost między słyszącymi a niesłyszącymi. Głusi mają kłopoty z długotrwałym czytaniem z ruchu warg (jest to czynność dość męcząca) ${ }^{7}$, słyszący zaś nie znają języka migowego - w tym wypadku skuteczne komunikowanie może umożliwić właśnie pismo znane obu grupom. Po drugie, pismo ułatwia ekspansję sztucznych języków migowych, które są gestowym odzwierciedleniem danego języka fonicznego. Osoba głucha, poruszając się w obrębie dwóch struktur językowych — migowej i fonicznej, zapośredniczonej przez pismo - w mniej lub bardziej uświadamiany sposób przenosi zasady jednej struktury do drugiej. Stąd owe niegramatyczne z punktu widzenia języka polskiego wypowiedzi głuchych na piśmie; stąd kontrowersje wokół „zanieczyszczania” języka migowego przez elementy mu obce: fleksję gramatyczną w miejsce fleksji przestrzennej. Tym właśnie sporom poświęcone będą dalsze rozważania. Postaram się ukazać kontekst społeczno-kulturowy funkcjonowania języka migowego, nie w opozycji, lecz raczej obok języka fonicznego.

\section{SPÓR O KULTURĘ, CZYLI „GŁUSI” I „GŁUSI”}

Gdyby szukać początków języków migowych, miejsc, gdzie te języki się narodziły, to byłoby to środowisko najbliższe osobom głuchym, czyli ich dom rodzinny. Języki wizualno-przestrzenne stosowane przez niesłyszących powstały bowiem jako sposób komunikowania się ze słyszącymi lub głuchymi najbliższymi ${ }^{8}$. Początki instytucjonalizacji języków migowych wiązane są z upowszechnieniem się szkolnictwa dla osób niesłyszących. To w szkołach spotykały się dzieci głuche $z$ różnych środowisk, porównywały sposoby komunikacji wyniesione $z$ rodzinnych domów i dokonywały standaryzacji języka na potrzeby porozumiewania się między sobą w środowisku szkolnym. Później, po

6 Fragment komentarza Molly55 zamieszczony na stronie: http://glusi.blox.pl/2007/10/ Glusi-nie-chca-pomocy.html\#ListaKomentarzy [11.06.2008].

7 Więcej: http://glusi.blox.pl/2007/10/Jak-mowic-wyraznie-do-gluchego.html [11.06.2008].

${ }^{8}$ Historię powstania języków migowych oraz charakterystykę ich funkcjonowania w środowisku polskich głuchych przybliżam na podstawie: wywiadu Olgi Woźniak z prof. Markiem Świdzińskim (http://wiadomosci.onsi.eu/info,264.html [11.06.2008]), informacji zamieszczonych na stronie http://pjm.interpsi.ok.pl/PJM/tabid/65/Default.aspx [11.06.2008], artykułu Olgi Woźniak Gtusi swój język maja (2008). 
opuszczeniu szkoły, ów język, ujednolicony co do stosowanych znaków i reguł ich łączenia, stawał się podstawowym sposobem komunikacji głuchych w ich środowisku, przekazywany był kolejnym osobom, w tym - przede wszystkim — dzieciom osób niesłyszących, i tym głuchym, i tym bez wad słuchu.

Podobną drogę, od znaków domowych, przez ujednolicanie w pierwszych szkołach dla niesłyszących, po upowszechnienie w środowisku osób głuchych, przebyły w zasadzie wszystkie znane języki wizualno-przestrzenne. Dlatego właśnie nie ma jednego naturalnego powszechnego języka migowego, znanego wszystkim głuchym na świecie, co więcej, mamy do czynienia z około dwustoma takimi językami ${ }^{9}$. Jak informuje na swoich stronach Instytut Polskiego Języka Migowego:

„Języki migowe, tak samo jak języki foniczne, różnią się między sobą, w zależności od tego, w jakim kraju i kręgu kulturowym doszło do ich powstania. W niektórych krajach używany jest jeden język migowy (na przykład PJM w Polsce, BSL w Wielkiej Brytanii, LSF we Francji). W innych krajach, w których obowiązuje więcej niż jeden język urzędowy (na przykład w Szwajcarii czy Belgii), występuje też kilka języków migowych. Może być również tak, że jeden język migowy stanowi narzędzie komunikacji w kilku różnych krajach (na przykład ASL w USA i Kanadzie). Języki migowe rozwijają się niezależnie od języków mówionych - stąd na przykład różnice pomiędzy ASL i BSL" ${ }^{10}$.

W Polsce powstanie języka migowego (określanego jako Polski Język Migowy - PJM) wiąże się z uruchomieniem w $1817 \mathrm{r}$. w Warszawie pierwszej szkoły dla głuchych - Instytutu Głuchoniemych, gdzie uczyły się dzieci niesłyszące $z$ zaboru rosyjskiego. To tam rozpoczął się proces unifikacji znaków domowych w jeden powszechnie stosowany język. Wkrótce podobne placówki dla głuchych dzieci zaczęły powstawać w pozostałych zaborach, a ośrodki te stały się kolejnymi zalążkami standaryzacji znaków języka migowego. To „szkolne rozbicie" spowodowało, że do dziś Polski Język Migowy nie jest jednorodnym systemem znaków i podobnie jak polski język foniczny ma gwary, regionalne dialekty, tak PJM ma własne regionalne wersje, które w mniejszym lub większym stopniu się różnią. Co więcej, język migowy podlega tym samym zróżnicowaniom co języki foniczne, ze względu na wiek, płeć, wykształcenie, pozycję społeczną jednostki.

Jednak PJM nie jest jedynym sposobem językowej komunikacji w społeczności polskich głuchych ${ }^{11}$. W latach sześćdziesiątych XX wieku, w środowisku surdopedagogów zgrupowanych wokół profesora Bogdana Szczepankowkiego,

\footnotetext{
${ }^{9}$ Jedyny powszechny międzynarodowy język migowy gestuno jest językiem sztucznym, podobnie jak sztuczny jest foniczny międzynarodowy język esperanto.

10 http://pjm.interpsi.ok.pl/PJM/tabid/65/TID/4/cid/1/Default.aspx [11.06.2008].

11 Jako sposób porozumiewania się, zwłaszcza w szkołach dla osób niesłyszących i niedosłyszących, wykorzystywane są również fonogesty. Jest to jednak metoda pomocnicza, bez statusu języka, wobec czego nie będzie przedmiotem mojego zainteresowania.
} 
powstał pomysł stworzenia sztucznego języka, który ułatwi komunikację między słyszącymi i niesłyszącymi ${ }^{12}$. Brano pod uwagę to, że PJM jest dość trudny do opanowania dla osób słyszących ze względu na inną gramatykę ${ }^{13}$. Z kolei dzieci głuche miały problem $z$ opanowaniem gramatyki języka polskiego, co przekładało się na kłopoty z pisaniem i czytaniem. Lekiem miał być System Językowo-Migowy (SJM, zwany także językiem miganym), czyli odwzorowanie $\mathrm{w}$ gestach słownictwa i gramatyki fonicznego języka polskiego. SJM wkrótce stał się obowiązkowym sposobem komunikacji w szkołach dla osób niesłyszących, a także w urzędach czy w telewizji (tłumacz migający w rogu telewizyjnego ekranu stosuje właśnie SJM). W Systemie zachowano wszelkie cechy fonicznego języka polskiego, których z kolei pozbawiony jest PJM, czyli gramatyczną fleksyjność (końcówki wyrazów migane są za pomocą alfabetu palcowego ${ }^{14}$ ), szyk zdania, a także zasadę, że jednemu słowu odpowiada jeden migany gest. Ponadto pokazywane znaki są uzupełnione głośną i wyraźną artykulacją słów (tak by umożliwić osobie głuchej czytanie z ruchu warg mówiącego), ale pozbawione wsparcia mimiki, jako że ekspresyjność przy miganiu, naturalna dla głuchych, sprawia duże trudności słyszącym.

Gdyby w środowisku polskich głuchych funkcjonowały tylko PJM i SJM, to sprawa wydawałaby się bardzo prosta. Tym bardziej że oba sposoby porozumiewania się przypisane zostały konkretnym sferom życia: PJM właściwy jest dla sfery prywatnej (rodzina, przyjaciele, znajomi), natomiast SJM używany jest w sferze publicznej (szkoły, urzędy, media). Jednakże nacisk, jaki kiedyś położono na „uoralnienie” głuchych, na konieczność opanowania przez nich choć częściowo mowy, a na pewno pisanego języka polskiego, sprawił, że na uprzywilejowanej pozycji znalazł się SJM. System najpierw stał się podstawą językowej edukacji głuchych w szkołach, a następnie jedynym uznawanym publicznie językiem porozumiewania się z osobami niesłyszącymi. Nie zmieniło to jednak faktu, że głusi między sobą (a więc także uczniowie w szkołach) posługiwali się PJM. Migający słyszący, na przykład nauczyciele, przejmowali

\footnotetext{
12 Tworzenie sztucznego języka w celu porozumiewania się z osobami niesłyszącymi nie jest przypadkiem czysto polskim. Na całym świecie powstawały takie sztuczne systemy komunikowania się z głuchymi, jako kolejny krok w polityce oralizmu. Więcej o zjawisku oralizmu w dalszej części tekstu.

13 Co więcej, jeśli potraktuje się język migowy jako obcy dla osób słyszących, to okazuje się, że nauka tego języka różni się nieco od nauki fonicznych języków obcych. W przypadku tych drugich zazwyczaj bierna znajomość języka (czyli na przykład czytanie, słuchanie) jest lepsza od znajomości czynnej (mówienia). W przypadku języka migowego częściej czynna znajomość języka (czyli miganie, choćby wykorzystujące tylko podstawowe słownictwo) jest lepsza od znajomości biernej (czyli odczytywania komunikatów osoby migającej). Związane jest to z brakiem przyzwyczajenia osób słyszących do wizualno-gestowego kanału komunikacji, co ujawnia się na przykład w niemożności jednoczesnego obserwowania miganych gestów i mimiki osoby migającej — słyszący nie mają nawyku korzystania z tzw. szerokiego kąta patrzenia.

${ }^{14} \mathrm{~W}$ języku migowym mamy zdanie „Mama pójść sklep”, w SJM (miganym): „Mama pójść szła do sklep u”, w języku polskim fonicznym: „Mama poszła do sklepu” — podaję za: http://glusi.blox.pl/2007/09/O-Polskim-Jezyku-Migowym.html [11.06.2008].
} 
więc znaki z PJM, a niesłyszący uczniowie wplatali we własny język zasady SJM. W efekcie w środowisku osób głuchych funkcjonują nie dwa sposoby komunikowania się, ale kilka. Mamy więc „czysty” PJM, „czysty” SJM oraz rozmaitego rodzaju hybrydy, które w różnych proporcjach wykorzystują znaki i struktury obu systemów językowych. Najczęściej spotykane hybrydy to albo unikanie daktylograficznych końcówek w SJM, albo dodawanie ich do znaków PJM. Oprócz tego oba języki wpływają na siebie wzajemnie, „pożyczając” sobie konkretne znaki, na takiej samej zasadzie jak w polskim języku fonicznym dochodzi do zapożyczeń z języków obcych.

Powyższa charakterystyka funkcjonujących w środowisku osób głuchych sposobów porozumiewania się jest konieczna do zrozumienia istoty sporu kulturowego, jaki toczy się wokół i wśród niesłyszących - sporu o kulturową odrębność osób głuchych. Wcześniej starałam się wykazać, na czym polega odrębność polskiego języka migowego od polskiego języka fonicznego, oraz przedstawiłam argumenty na rzecz uznania języka migowego za pełnoprawny język ludzki. Konsekwencją takiego podejścia jest przyznanie społeczności posługującej się językiem migowym praw grupy odrębnej kulturowo - w tym wypadku: praw mniejszości językowej. Takie właśnie stanowisko prezentuje część środowiska niesłyszących oraz badacze skupieni wokół Polskiego Instytutu Języka Migowego. Warto jednak dodać, że nie jest to podejście powszechnie podzielane i nie wzbudzające kontrowersji. Ponieważ niniejszy artykuł nie aspiruje do miana całościowej monografii, stanowi jedynie próbę opisu niektórych aspektów interesującego mnie zagadnienia. Stąd brak poparcia formułowanych tez w obszernym materiale empirycznym - korzystałam jedynie $z$ dostępnych w internecie materiałów: artykułów, blogów i forów prowadzonych przez osoby niesłyszące. Zdaję sobie jednak sprawę, że rzeczywistość internetowa nie odzwierciedla wszelkich problemów osób głuchych i zagadnienie to wymaga całościowych i dogłębnych badań, zwłaszcza że dotyczy tak istotnej sprawy, jak rozstrzygnięcie kwestii odrębności kulturowej osób głuchych.

Kultura na gruncie nauk społecznych definiowana jest w rozmaity sposób. Według klasycznej definicji Edwarda Tylora jest to „złożona całość obejmująca wiedzę, wierzenie, sztukę, prawo, moralność, obyczaje i wszystkie inne zdolności i nawyki nabyte przez człowieka jako członka społeczeństwa" (za: Kłoskowska 2007, s. 22). Pod pojęciem owych „innych zdolności i nawyków”, nabytych w społeczny sposób, niewątpliwie mieści się język. Jego znaczenie, jako elementu kultury, podnosi to, iż pośród różnych kategorii kultury wyróżnia się kulturę symboliczną, zawierającą uznane przekonania, poglądy, idee, systemy znaczeń i symboli wyrażane przede wszystkim właśnie za pomocą języka (por. Kłoskowska 2007, s. 67 i nast.; Sztompka 2004, s. 239). Wracając w tym miejscu do przytoczonych na początku argumentów na rzecz społecznej istotności języka, można uznać, że zróżnicowanie językowe grup społecznych jest podstawą do uznawania ich kulturowej odrębności. Skoro bowiem język jest systemem symbolicznym, który nie tylko konstytuuje kulturę, ale i pośredniczy 
w jej przekazywaniu, to właśnie w nim uwidacznia się to, co różnicuje społeczności odmienne kulturowo. Owo założenie o szczególnej roli języka w kształtowaniu kulturowej inności jest niezmiernie istotne w rozważaniach dotyczących narodu i narodowości - tam język stanowi ważne kryterium przynależności narodowej i kulturowej tożsamości danej grupy etnicznej. I właśnie $z$ zakresu socjologii narodu pochodzi pojęcie mniejszości kulturowo-ideologicznych, do których zalicza się interesujące mnie w tym miejscu mniejszości językowe.

Kwestia przyznania głuchym miana mniejszości językowej jest dość kontrowersyjna. Głusi zwyczajowo traktowani są jako niepełnosprawni, na równi z osobami, które mają wady wzroku, narządów ruchu czy różne stopnie upośledzenia intelektualnego. Same osoby niesłyszące nie do końca potrafią się z tym zgodzić. $Z$ jednej strony część $z$ nich nie neguje tego, że ich narząd słuchu jest w mniejszym lub większym stopniu obarczony wadą. $Z$ drugiej jednak pojawiają się głosy, że to nie wada, a wyróżnik, powód do dumy, tak jak inny kolor skóry. Jedna z niesłyszących na swoim blogu, poruszając kwestię "głuchota a niepełnosprawność", napisała:

„Otóż to, jedyny nasz problem ze światem słyszących polega na ograniczonej, albo braku komunikacji. Oczywiście, gdy są dobre chęci, to zawsze możemy pisać w zeszycie [...] Problem nasz jest taki sam więc jak mają cudzoziemcy w Polsce. Przyjeżdżają, nie znając naszego języka. Jednak to nie znaczy, że są niepełnosprawni, nie? Po prostu trzeba poznać ich język i można z nimi się dogadać! Tak samo jest z nami, Głuchymi" 15 .

Użytkowniczka forum http://deaf.pl zapytała z kolei:

„Mam pytanie do was czy uważacie, że osób Głuchych należy do kategorii niespełnosprawni czy należy się oddzielne? Ja uważam, że nie!! my Glusi jesteśmy tacy sami co Górale, wielkopolanie, ślązacy, kaszubscy, syberyjski co nie zrozumiałe dla rodowite Polaków. I mamy wspólne dwa świat. Tylko po co pchamy do kategori niespełnosprawni i dostajemy kiepską pomocy i trudnością ze zrozumieniem ze światem normalnością dlatego, że ci normalności nie rozumieją Gluchych i wypchali Głuchych poza margines normalności i automatyczne zapisane do niespełnosprawni. Na zachodni tak nie robią. Raczej wpólpracują się i rozwijają się"16.

I uzyskała taką między innymi odpowiedź:

„Bo generalnie są dwa podejścia, dwa spojrzenia na g/Głuchych — jedno medyczne (głuchota to problem medyczny, patologia) i niemedyczne (Głuchota to problem społeczno-kulturowo-polityczny). Na zachodzie, nie tylko w Niemczech to drugie podejście jest bardzo popularne, u nas nie. Może dlatego, że tam ludzie już dawno oswoili się z mnogością kultur i języków (liczne mniejszosci emigrantów)..."17

15 http://glusi.blox.pl/2007/09/Czy-gluchota-jest-niepelnosprawnoscia.html [11.06.2008].

16 http://www.deaf.pl/forum_deaf,topic,7667.0.html [11.06.2008].

17 http://www.deaf.pl/forum_deaf,topic,7667.0.html [11.06.2008]. 
Głuchota może być więc traktowana nie jako niepełnosprawność, ale jako kulturowy wyróżnik. W konsekwencji mamy do czynienia z mniejszością językową, której naturalnym językiem jest migowy. $\mathrm{Na}$ tej podstawie formowana jest tożsamość kulturowa osoby głuchej, odrębna od kulturowej tożsamości osoby słyszącej. Głuchy jest więc „cudzoziemcem” wśród słyszących, co podkreślane jest dodatkowo zapisem "Głuchy” — jako nazwa własna zamiast pospolitego rzeczownika "głuchy” 18 .

Wydaje się, że kulturowa tożsamość osób niesłyszących tak naprawdę jest tworzona nie $\mathrm{w}$ opozycji do kultury polskiej (jak w przypadku mniejszości narodowych i etnicznych), ale raczej jako przeciwstawienie się kulturze słyszących. Opozycja Głuchy-Słyszący jest więc najważniejsza. Potwierdzenie można znaleźć w specyficznej klasyfikacji, wedle której kulturowo głuche osoby porządkują świat wokół siebie; klasyfikacji, w której czynniki biologiczne (ubytek słuchu bądź nie) połączone są z czynnikami kulturowymi (język) ${ }^{19}$. Ze względu na sprawność narządu słuchu mamy więc „słyszących” (bez ubytków), „niesłyszących" (z ubytkiem, ale w różnym stopniu, a więc i niedosłyszących, i słabosłyszących) oraz „głuchych” (tylko ubytek poważny lub całkowity). Z kolei ze względu na tożsamość kulturową mamy do czynienia ze „Słyszącymi” (osoby słyszące, niesłyszące lub głuche, które nie partycypują w głuchej kulturze, co oznacza przede wszystkim brak umiejętności posługiwania się językiem migowym) i „Głuchymi” (osoby głuche, które definiują siebie jako przynależnych do odrębnej kulturowo społeczności Głuchych, czyli takich, którzy preferują „mówienie” PJM nad inne sposoby komunikowania się).

Słyszący zazwyczaj nazywani są słyszakami/Słyszakami. Pojęcie to nie jest jednoznacznie wartościowane. Dla części głuchych słyszak jest po prostu potocznym określeniem kogoś, kto słyszy, i dlatego pisane jest małą literą. Z kolei dla innych, pisany wielką literą Słyszak jest pojęciem wartościowanym negatywnie i stanowi swoistego rodzaju obelgę. Słyszakiem jest ten, kto identyfikuje się z kulturą Słyszących i nie ma w sobie żadnego zrozumienia dla kultury Głuchych. Co więcej, deprecjonuje kulturę Głuchych, zarzuca jej prymitywizm, odmawia językowi migowemu statusu pełnoprawnego języka ludzkiego i uważa niesłyszących za osoby niepełnosprawne, którym trzeba pomóc przez rehabilitację i implantowanie. Słyszakiem może być zarówno ktoś, kto słyszy, jak i osoba głucha, która „wyrzekła” się kulturowej przynależności do Głuchych.

18 Dalej będę stosowała dwojakiego rodzaju nomenklaturę: „głusi” dla oznaczenia osób niesłyszących z dużym lub całkowitym ubytkiem słuchu i "Głusi”, gdy mowa będzie o osobach kulturowo głuchych. Warto w tym miejscu dodać, że wśród osób z ubytkami słuchu nie ma pełnej zgody co do własnej nazwy. Niektórzy wolą określenie „niesłyszący” zamiast „głuchy” — na wzór „niewidomy”, a nie „ślepy”; dla innych miano „głuchy”, a zwłaszcza "Głuchy” stanowi powód do dumy i wyróżnik kulturowy — zob: http://www.deaf.pl/forum_deaf,topic,2232.0.html [11.06.2008]. Dlatego też nie używam tu jednego określenia, ale obu: i „niesłyszący”, i „głuchy”, jako synonimów.

$19 \mathrm{Na}$ podstawie: http://glusi.blox.pl/2008/01/Definicje-WAZNE-w-Swiecie-Gluchych.html [11.06.2008]. 
Funkcjonowanie pojęcia Słyszaka staje się często podstawą do oskarżania Głuchych o „kulturowy rasizm” względem innych niż Głuche grup społecznych. Z kolei Głusi zarzucają Słyszakom audyzm, czyli „przemoc oralną”, lekceważenie kultury Głuchych, traktowanie osób niesłyszących jako niepełnosprawnych, niezdolnych do samodzielnego i pełnego funkcjonowania w społeczeństwie, wśród słyszącej większości ${ }^{20}$.

W świetle analizowanej wyżej klasyfikacji problemem jest Głucha tożsamość osób słabosłyszących, które najczęściej mają nikły kontakt z językiem migowym i są poddawane rehabilitacji narządu słuchu - to grupa osób „pomiędzy", nieprzynależna ani do Głuchych (bo nie znająca PJM, posługująca się mową werbalna), ani do Słyszących (bo jednak ich kompetencje oralne są ograniczone). Sami słabosłyszący czasami narzekają także na „kulturowy rasizm" Głuchych, dla których podobieństwo biologiczne (wada słuchu) jest zbyt małym argumentem na rzecz zaakceptowania w swym gronie osób znających „niewłaściwy” język (mowa zamiast PJM). Z kolei dla Głuchych nieposługująca się w zasadzie PJM osoba słabosłysząca niewiele różni się od słyszącej większości, zwłaszcza jeśli nie przejawia chęci poznania języka migowego i stara się za wszelką cenę nie przyznawać do własnej wady słuchu ${ }^{21}$.

Jak wcześniej wspomniałam, podział na g/Głuchych i s/Słyszących wykorzystuje dwa kryteria: biologiczne (ubytek słuchu bądź nie) i kulturowe (posługiwanie się językiem migowym i w efekcie partycypowanie w kulturze Głuchych). Z punktu widzenia tej klasyfikacji interesujące są dwa przypadki: gdy niesłyszący rodzice mają słyszące dziecko oraz gdy słyszącym rodzicom rodzi się dziecko niesłyszące. Jeśli weźmiemy pod uwagę fakt, że kultura (którą uosabia tu język) jest przekazywana przede wszystkim w drodze socjalizacji, to okazuje się, że na skutek splotu czynników biologicznych i kulturowych takie dzieci wychowywane są w środowisku odmiennym kulturowo niż wynika to $z$ ich fizyczności. Rozpatrzmy więc oba przypadki jako najpełniej uwidaczniające kulturowe spięcie między światem słyszących i niesłyszących.

20 Patrz: http://www.deaf.pl/forum_deaf,topic,8475.0.html [11.06.2008].

${ }^{21}$ Jako przykład chciałabym podać dwie wypowiedzi z forum http://www.deaf.pl — jedna osoby słabosłyszącej, aspirującej do kultury Głuchych: „To co pisałaś o tożsamości, o dwóch światach jest mi bardzo bliskie i cały czas tak odczuwam. Trudno jest sie odnaleźć. Chodziłam przez dłuższy czas do szkoły masowej, nie miałam problemów z nauką i porozumiewaniem się, ale czułam że nie chciałam tam być, że tam nie pasuję, wiec przeniosłam sie do szkoły z internatem dla głuchych wiedząc, że spotkam tam ludzi podobnych do mnie. I tak się stało, z tym że spotkałam tylko kilka osób słabosłyszących, a większość z nich nie znała dobrze j. migowego. Z tego powodu trudno im było się swobodnie porozumieć z głuchymi. Poza tym świat głuchych jest wyjątkowy, trzeba się urodzić głuchym żeby w pełni do niego należeć, dają oni to do zrozumienia nawet tym, którzy znają PJM i są Głuchymi ... zazdroszczę im.”; oraz druga — wypowiedź osoby Głuchej: „ja sama stanowczo wolę przebywać z Głuchymi niż słabosłyszącymi, zbliżony sposób postrzegania świata, ukończone te same szkoły, wspólni znajomi, wspólne tematy... A słabosłyszący przeważnie nie umieją migać, ech, biedacy..." 
Słyszące dzieci głuchych rodziców nazywane są CODA (Child/Children of Deaf Adults) ${ }^{22}$. CODA wzrasta w kulturze Głuchych, a język migowy jest jego naturalnym pierwszym językiem - w toku socjalizacji uczy się go od niesłyszących rodziców. Sam jednak nie ma kłopotów z opanowaniem poprawnego języka fonicznego, a jego szkolna edukacja przebiega w środowisku słyszących. Ponieważ zazwyczaj posługuje się sprawnie dwoma językami, uznawany jest za osobę dwukulturową - nie spotka się z odrzuceniem ani ze strony Głuchych, ani ze strony Słyszących. W efekcie CODA funkcjonuje na pograniczu dwóch światów: „CODA, którzy opanowali oba te języki w stopniu porównywalnym, przeżywają największe rozdarcie wewnętrzne (bo nie wiedzą, który język i która kultura są w nich dominujące)" 23. Podwójna tożsamość kulturowa bywa dla niego dość dużym kłopotem poznawczym, przy czym jeśli już, to problem stanowi "Głuche dziedzictwo" - kultura Głuchych jest bowiem kulturą mniejszościową, a pełne uczestnictwo w życiu całego społeczeństwa wiąże się z operowaniem językiem fonicznym. Dlatego też grupę CODA dzieli się na pozytywnych (którzy własną kulturową głuchotę zaakceptowali) i negatywnych (którzy odrzucili kulturę Głuchych). Warto dodać w tym miejscu jeszcze jedno: nawet jeśli CODA straci słuch, to dla społeczności Głuchych i tak pozostanie „słyszącym-niesłyszącym”, nigdy nikt nie określi go mianem Głuchego ${ }^{24}$.

Mimo że CODA żyje na pograniczu świata słyszącego i niesłyszącego, to nie stanowi „obcego" w żadnym $z$ nich. Przez głuchych jest akceptowany z racji rodziny pochodzenia, dla słyszących jego kulturowa Głuchota jest „przezroczysta" - skoro bowiem sprawnie posługuje się językiem fonicznym, to nikt nie domyśli się, że CODA „mówi” także w języku migowym. Słyszący nie martwią się także zbytnio o kompetencje językowe takiego dziecka, bo choć jego dom jest pogrążony w ciszy, to cały świat dookoła rozbrzmiewa dźwiękami i mową. Inaczej jest $\mathrm{w}$ przypadku niesłyszących dzieci słyszących rodziców. Jakkolwiek patetycznie by to zabrzmiało, to los takich dzieci jest polem walki między słyszącymi a głuchymi o to, w jakiej kulturze zostaną wychowane i jak ukształtowana zostanie ich kulturowa tożsamość. Słyszący rodzice chcą, by ich dziecko jak najlepiej radziło sobie w świecie dźwięków i języka fonicznego - stąd intensywna rehabilitacja, nauka mowy i poddawanie dzieci operacjom wszczepienia implantów. Działanie to wydaje się całkowicie zrozumiałe, jeśli weźmiemy pod uwagę zdecydowaną dominację kultury Słyszących. Jednakże każde $z$ tych zachowań budzi sprzeciw niektórych Głuchych, przy czym z największym oporem spotyka się implantowanie. W tym miejscu chcia-

22 Dla porządku dodam, że istnieją także SODA (Sibling of the Deaf Adults), czyli słyszące rodzeństwo osób głuchych, a jedyna słysząca osoba w rodzinie, w której i rodzicie, i rodzeństwo nie słyszą, to OHCODA (Only Hearing Child of Deaf Adults).

23 http://www.deaf.pl/forum_deaf,topic,7265.40.html [11.06.2008].

24 Więcej na forum http://www.deaf.pl/forum_deaf,topic,7704.0.html [11.06.2008]. 
łabym krótko przedstawić sytuację osób nazywanych Implantowcami z punktu widzenia środowiska Głuchych zaangażowanych w obronę własnej kultury.

Implantowcy to osoby, które świadomie (jako dorośli) albo nieświadomie (jako dzieci, decyzją rodziców) z pomocą interwencji chirurgicznej (wszczepienie implantu ślimakowego) zostały „oderwane” od kultury Głuchych i przeniesione w świat Słyszących. Celowo rozróżniłam dorosłych i dzieci, ponieważ z punktu widzenia kształtowania się tożsamości kulturowej są to dwie odrębne sytuacje. Dorosły, który poddaje się implantowaniu, podejmuje świadomą decyzję, by słyszeć. W ten sposób niejako symbolicznie odseparowuje się od środowiska głuchych, czasem porzuca język migowy na rzecz języka fonicznego i zaczyna Słyszeć. Jest kulturowym konwertytą. I tak jak w przypadku konwersji narodowych (co opisywała między innymi Antonina Kłoskowska w Kulturach narodowych $u$ korzeni) dorosły Implantowiec narażony jest na tożsamościowe perturbacje, poczucie bycia kulturowym bezpaństwowcem, bo i grupa, z której odszedł (Głusi), i ta, do której stara się przynależeć (Słyszący), może go nigdy całkowicie nie zaakceptować — jednych „zdradził”, dla drugich zawsze będzie „innym" 25.

W przypadku implantowanych dzieci nie można mówić o kulturowej konwersji - dzieci te, najczęściej słyszących rodziców, zazwyczaj nigdy nie poznają kultury Głuchych, nie uczą się języka migowego, a przez wszczepienie implantu i rehabilitację są "przystosowywane” do bycia słyszącym. W ich dorosłym życiu możliwy jest dwojaki scenariusz. Po pierwsze, w pełni mogą stać się Słyszącymi, dla których kultura Głuchych będzie równie egzotyczna jak dla ich rodziców. Po drugie, możliwy jest również kryzys tożsamości, wynikający z poczucia obcości w świecie słyszących. W takim wypadku implantowany szuka kontaktu z osobami niesłyszącymi i stara się zbliżyć do kultury Głuchych. Jest to sytuacja podobna tej w świecie kultur narodowych, gdy na przykład po latach Polak odkrywa, że ma korzenie niemieckie lub żydowskie, szuka więc ich, jedzie do kraju przodków itd. Próba odbudowania własnej tożsamości, tym razem na dwukulturowych podstawach, w przypadku implantowanych jako dzieci jest

25 Forum http://www.deaf.pl jest jednym $z$ miejsc w polskim internecie, gdzie sporo dyskutuje się o kulturze Głuchych, w związku z czym można tam spotkać wiele osób bardzo zaangażowanych w propagowanie i obronę tej kultury. Podczas jednej z rozmów na temat implantacji i statusu osób implantowanych jeden z użytkowników, sam noszący implant, napisał: „Gdy mi ktoś opowiadał o podziałach między niesłyszącymi, nie wierzyłem $w$ nie za bardzo, bo nigdzie się z nimi nie spotkałem. Dopiero tutaj, na forum i na chacie je zauważyłem - faktycznie są i potrafią ludziom uprzykrzyć życie. Krążą stereotypy o szkodliwości implantów, o zmuszaniu do implantowania i wywyższaniu się implantowanych. Może to dziwne, ale zauważyłem, że występują one właściwie tylko wśród Głuchych. Czemu? Uprzedzenia? Ja sam nigdy się z czymś takim nie spotkałem. Uskarżacie się na nietolerancję wśród słyszących, a sami nie tolerujecie dużej grupy osób niesłyszących, która się zdecydowała na inną, niż standardowe, protezę słuchu. M. - a powiedz mi, co mają zrobić implantowani, którzy Twoim zdaniem się gubią, skoro środowisko Głuchych nie chce ich zaakceptować? Ja, choć mam implant, wcale się nie czuję słyszący" - zamieszczone na stronie: http://www.deaf.pl/forum_deaf,topic,7493.40.html 
jednak trudna. Po pierwsze, nie są w stanie opanować w stopniu wystarczającym naturalnego języka migowego, który dla nich jest tak samo językiem obcym, jak dla słyszących. Po drugie, dla Głuchych są i pozostaną zawsze Słyszącymi, a więc osobami wychowanymi w obcej kulturze (właśnie ze względu na język socjalizacji) - stąd możliwość braku akceptacji „nawracających” się na Głuchotę Implantowców.

Na forum http://www.deaf.pl, w jednej z rozmów można przeczytać taką wymianę zdań:

Osoba zaimplantowana: „Coraz bardziej mnie ciekawi, dlaczego niektorzy z Was odrzucają Implantowcow bez uprzedniego zapoznania?? Bardzo duzo na temat implantu czytalam i ja od samego poczatku nie ukrywalam, ze jestem osoba z implantem. Generalnie czuje sie osoba Glucha i mnie rani to, jak niektorzy patrza na to, co ja mam za uchem, a nie na to jaka ja mam osobowosc. Wychowywalam sie w rodzinie slyszacej, gdzie nauczono mnie mówic, zostalam poddana operacji, bo w aparatach sluchowych doslownie NIC nie slyszałam, nie ukrywam, ze kawal zycia spedzilam w swiecie slyszacych, i po wielu latach przenioslam sie do swiata gluchych. Nie ukrywam, ze niektorzy mnie odrzucali, bo mam implant, a ja naprawde chcialam poznac swiat Gluchych i czasem nie moge ciagle udowadniac, ze jestem po stronie Gluchych... przeciez to niewazne, czy ja mam implant, czy nie, ale chyba najwazniejsze jest to, jaki ja mam stosunek do Gluchych"

Osoba Głucha: „Ja nie odrzucam, ani trochę. Tylko odrzucam przesadny szum wokół tego "cacka", nadmierne wychwalanie w mediach, a pokątnie znajomi przyznają - nie zawsze jest tak różowo. Tak więc - nie wiem, dlaczego inni odrzucają Twoją osobę, zapytaj o to ich wprost. Pewnie sami nie będą wiedzieli, albo po prostu powiedzą "Bo jesteś jak słysząca». A tu zawsze jest problem. Słysząca, czyli nie Głucha. Zwłaszcza, jak sama mówiłaś, byłaś kawał życia ze słyszącymi."

CODA: „Z moich skromnych obserwacji wynika, że «środowisko» nie odrzuca nikogo ze względu na sam implant. [...] to kwestia mentalności, znajomości języka migowego, przestrzegania obowiązujących norm i zasad. Każdy, kto nie jest «stuprocentowym Gluchym» musi się przygotować na to, że nie przez wszystkich będzie akceptowany..."

Osoba zaimplantowana: „Masz rację, ze to moze byc kwestia mentalnosci, znajomosc j migowego, ale wtedy jak probowałam wejsc do świata Głuchych nikt nie chciał mnie nauczyć j migowego, miałam szczescie ze był jeden koles ktory cierpliwie przez pół roku mnie nauczył migac a później probowałam sama swoich sił poruszać sie po świecie Głuchych. Niezawsze była taka sielanka zawsze mi powtarzali, ze «Ty to nigdy nie bedziesz z nami bo masz implant", "ze nie warto mnie nauczyć migac, bo wole mówić», «ze ja nigdy nie zrozumiem Głuchych bo faktycznie jestem słysząca...» i dzis choć mniej ale wciąż to samo słysze... a ja przecież nie rzucę implantu $z$ ich powodu..." 26 .

\footnotetext{
26 http://www.deaf.pl/forum_deaf,topic,7290.0.html [11.06.2008].

Z kolei na forum http://forum.alldeaf.pl zaimplantowana $\mathrm{w}$ dzieciństwie użytkowniczka pisze o własnej tożsamości tak: „to było przeszkadzało przez hałas, i jeszcze dlaczego ja przerwałam,
} 
Z punktu widzenia słyszących implantowanie jest sposobem na walkę z niepełnosprawnością, na umożliwienie głuchym pełnego funkcjonowania wśród słyszącej, posługującej się mową większości. Zaimplantowana osoba łatwiej nauczy się języka fonicznego, a co za tym idzie - mniej będzie miała problemów komunikacyjnych w życiu codziennym. Jest to więc przede wszystkim niwelowanie fizycznej ułomności, co pośrednio ma pomóc w pełnej, „fonicznej" akulturacji dziecka. Z kolei dla Głuchych implantowanie dzieci to próba pozbawienia ich właściwego im dziedzictwa kulturowego — rodzaj oralnej przemocy. Warto jednak dodać, że o ile implanty budzą duże emocje, o tyle przez Głuchych bezproblemowo akceptowane są aparaty słuchowe - różnica zapewne tkwi w tym, że implant wydaje się rozwiązaniem o wiele trwalszym: można go, co prawda, wyłączyć, ale koszty, jakie poniosła osoba zaimplantowana (chociażby sama operacja wszczepienia), sprawiają, że niełatwo z niego zrezygnować. Ponadto implant jest ingerencją $w$ biologiczną strukturę organizmu, podczas gdy aparat słuchowy to prosta do odrzucenia proteza.

Niechęć Głuchych wobec implantowania dzieci wiąże się z kolejną kwestią: troską o transmisję międzypokoleniową kultury Głuchych. W łagodnej formie jest to po prostu działalność na rzecz edukowania słyszących rodziców głuchych dzieci, by te mogły stać się pełnoprawnymi Głuchymi. Niesłyszące dzieci z rodzin słyszących i głuchych powinny mieć szansę na poznanie obu kultur Głuchej, do której przynależą z racji ubytku słuchu, i Słyszącej, jako tej kultury, która dominuje w społeczeństwie. Stąd apel o edukację dwujęzyczną: najpierw naturalny język, czyli PJM, potem język polski, by poprawnie wypowiadać się na piśmie. Dopiero następnym krokiem mogłaby być nauka mowy ${ }^{27}$. Jest to kwestia o tyle istotna, że transmisja kultury Głuchych nie odbywa się przede wszystkim w rodzinie - tak jak w kulturze Słyszących — lecz w placówkach edukacyjnych. Większość głuchych dzieci ma bowiem słyszących rodziców i dla nich miejscem „głuchej” akulturacji jest szkoła. Tam spotykają inne niesłyszące dzieci, także te $z$ rodzin głuchych, tam poznają język migowy. Jeśli placówki edukacyjne będą zdominowane przez nauczanie w SJM, to głuche dzieci ze słyszących rodzin nie będą miały żadnych szans na ukształtowanie w sobie Głuchej tożsamości kulturowej ${ }^{28}$.

bo nic nie czułam chętnych do słyszenia, i chętnie by czuła jak prawdiwa Głucha. Ale ogólnie $z$ implantem muszę nosić, bo po co ja mam implant, którzy moi rodzice to zdecydowali. I tak ogólnie nie żałuję, że ja mam implantu. Tylko, że ja żyję w świecie Głuchych :) jak ja uwielbiam"; http://forum.alldeaf.pl/topics219/2229,15.htm [11.06.2008].

Na forum http://www.deaf.pl zamieszczona jest także opowieść o szokującym odkryciu własnej „podwójnej” tożsamości przez osobę, która, co prawda, nie została implantowana jako dziecko, ale decyzją rodziców miała być Słysząca; http://www.deaf.pl/forum_deaf,topic,3285.0.html [11.06.2008].

27 Por. http://www.deaf.pl/forum_deaf,topic,7176.0.html [11.06.2008].

28 Por. wypowiedź z forum http://www.deaf.pl: „To jest właśnie jedna z charakterystycznych cech kultury Głuchych... «Normalnie» kultura jest przekazywana z pokolenia na pokolenie w ro- 
W postaci radykalnej troska o transmisję międzypokoleniową kultury Głuchych przybiera postać zdecydowanych deklaracji, że nie zaimplantuje się własnego dziecka, co więcej — pragnie się, by ono także było głuche. Ten radykalizm nie jest jednak powszechny i wśród samych Głuchych budzi kontrowersje. $\mathrm{Na}$ wielokrotnie cytowanym przeze mnie forum http://www.deaf.pl kilkakrotnie dyskutowano o posiadaniu głuchych dzieci. Pojawiały się opinie zarówno „za":

„Ja bym chciała mieć dziecko Głuche, z pewności byłabym szczęsliwa. A mój powód: Wspólna świat, kultura, porozumienie, akceptacja, z pewnością w przyszłości nie zostanie zlekceważone!"

„Wspólne środowisko, kultura, język. Nie ma między mną a moim dzieckiem nawet najmniejszej bariery. Zresztą w liceum spotkałam się $z$ wieloma przypadkami że dzieci zazdrościły mi głuchych rodziców, mówiły: «Ty to masz fajnie, wszyscy migacie i się wzajemnie rozumiecie». Chcę by moje dziecko miało takie samo szczęście jak ja",

jak i wypowiedzi, wyrażające zdecydowany sprzeciw:

„Wołałbym, aby moje dzieci były słyszące, a gdyby było to głuche dziecko nie dopuściłbym do zamknięcia "hermetycznego kręgu» i dałbym dziecku z całego serca, aby mógł normalnie funkcjonował w codziennym zyciu! Rodziców, którzy chca mniec głuchego dziecka nie popieram!"

„Polska nie jest krajem tolerancyjnym. Nie ma co się oszukiwać. Zabawne jest to, że nigdy nie spotkała mnie żadna przykrość ze strony ludzi na mój niedosłuch, a jeśli przyszło co do czego (czyt.: praca), nikt nie chciał zaufać. Nie. Nie chcę, by moje dziecko miało wadę słuchu. Nie zdecyduję się na dziecko, jeśli okaże się, że ta wada jest wrodzona" 29 .

Najbardziej skrajnym przypadkiem, niemożliwym na razie w Polsce do zrealizowania, choć w innych krajach dochodziło już do podobnych zdarzeń, jest genetyczna selekcja zarodków podczas zapłodnienia in vitro tak, by głusi rodzice mieli absolutną pewność, że urodzi się głuche dziecko. Tego typu praktyka jest potępiana zarówno przez Słyszących, jak i przez Głuchych. Można by rzec, że troska o transmisję kultury i chęć dzielenia $z$ dzieckiem wspólnego świata kulturowego to jedno, a manipulacje genetyczne - to drugie ${ }^{30}$.

dzinie. Spośród głuchych dzieci tylko 10\% posiada Głuchych rodziców (niektóre źródła podają, że jeszcze mniej). Wyjątkowość kultury Głuchych polega między innymi i na tym, że przejmuje się ją przeważnie od starszych kolegów i rówieśników. Jest to jeden z powodów, dla których społeczności Głuchych na świecie tak ostro sprzeciwiają się likwidacji tradycyjnych szkół z internatem"; http://www.deaf.pl/forum_deaf,topic,7265.40.html [11.06.2008].

29 http://www.deaf.pl/forum_deaf,topic,9644.0.html [11.06.2008] i http://www.deaf.pl/ forum_deaf,topic,4745.msg30790.html [11.06.2008].

30 Warto zapoznać się z artykułem Artura Włodarskiego Jest doskonaty (2002) oraz dyskusjami na forach http://forum.alldeaf.pl/topics320/3639.htm? sid=49ebb16227e2a004981f9edf27281e07 [11.06.2008], http://www.deaf.pl/forum_deaf,topic,9644.0.html [11.06.2008] oraz http:// www.deaf.pl/forum_deaf,topic,9760.0.html [11.06.2008]. 
Wszczepianie implantów to nie jedyna kwestia, która ujawnia napięcie między światem słyszących i niesłyszących. Wpisuje się ona w szerszy problem, jakim jest relacja między językiem migowym (PJM), miganym (SJM) i fonicznym językiem polskim. Jest to sprawa istotna, ponieważ tożsamość kulturowa Głuchych zbudowana jest przede wszystkim na odrębności językowej. Rozważanie relacji pomiędzy wymienionymi trzema sposobami porozumiewania się jest zagadnieniem zbyt obszernym, aby w tym miejscu uczynić to dogłębnie. Dlatego też postaram się pokazać najważniejsze wątki sporu o język i kulturę Głuchych na wybranym przykładzie: akcji Niemego Protestu.

W wieczornych Faktach telewizji TVN, wyemitowanych 18 marca 2008 r., pojawił się materiał Renaty Kijowskiej o maturalnych szansach osób niesłyszących. Reporterka wskazywała, że z powodu kłopotów ze zrozumieniem języka polskiego głusi boją się zdawać egzaminy maturalne, a brak matury uniemożliwia im na przykład studiowanie. Reportaż kończył się sugestią uproszczenia arkuszy maturalnych i dostosowania ich do ubogiej polszczyzny głuchych ${ }^{31}$. Emisja tego materiału spotkała się ze zdecydowaną reakcją niesłyszących — na forach, blogach i stronach internetowych pojawiły się wpisy Niemego Protestu.

Głusi wysunęli szereg zarzutów pod adresem Renaty Kijowskiej, oskarżając ją o ignorancję i przedstawianie środowiska polskich niesłyszących w fałszywym świetle ${ }^{32}$. Najwięcej emocji spowodowało jedno zdanie: "Język migany, którym się [niesłyszący] posługują, zna tylko 7 tysięcy słów". Reporterce wytykano, że - po pierwsze - polscy głusi w przeważającej części posługują się językiem migowym (PJM), a nie miganym (SJM). Po drugie, język migowy zawiera więcej niż kilka tysięcy znaków i nie jest pozbawiony synonimów. Co więcej, PJM zawiera znaki, których znaczenia nie sposób przełożyć na język polski jednym lub dwoma słowami - wynika to po prostu z odmiennej struktury obu języków. Po trzecie, głusi wcale nie boją się matury, a jeśli do niej przystępują, to nie zawsze kończy się to porażką. Po czwarte, propozycja obniżenia poziomu egzaminu maturalnego dla głuchych jest obraźliwa, bo sugeruje, że niesłyszący są mniej inteligentni. Po piąte, reporterka nie dostrzegła prawdziwego źródła problemu, którym wedle głuchych jest wciąż pokutująca $\mathrm{w}$ Polsce polityka oralizmu i deprecjonowanie języka migowego.

Doktryna oralizmu ma swoje początki w XIX wieku ${ }^{33}$. Wtedy to, w 1880 r., na kongresie $\mathrm{w}$ Mediolanie, poświęconym edukacji osób niesłyszących, po-

\footnotetext{
31 Reportaż w całości można obejrzeć na stronie: http://pl.youtube.com/watch?v= 0xN-XLy9VKA [11.06.2008].

32 Przykładowe informacje o proteście: http://www.niemyprotest.pl/info,1538.html [11.06. 2008]; http://pl.youtube.com/video_response_view_all?v=0xN-XLy9VKA [11.06.2008]; http:// glusi.blox.pl/2008/03/PROTEST.html [11.06.2008]; http://migofil.blogspot.com/2008/03/walczymy.html [11.06.2008].

33 Na postawie artykułu Marka Świdzińskiego Po głuchoniemsku (2003), zamieszczonego na stronie: http://wiadomosci.onsi.eu/info,338.html [11.06.2008], a także http://www.ifp.uni.wroc.pl/ forum/viewtopic.php? $\mathrm{t}=1529$ \&postdays $=0$ \&postorder $=$ asc\&start $=15$ [11.06.2008].
} 
stanowiono, że język migowy jest prymitywnym sposobem porozumiewania się i należy głuchych uczyć mowy - taką postawę głusi nazywają audyzmem („fonicznym rasizmem”). Mniej więcej pół wieku po mediolańskich obradach zorientowano się, że taka polityka nie przynosi pożądanych rezultatów i w kolejnych krajach zaczęły powstawać sztuczne języki migowe - miały być kompromisem między naturalnym językiem migowym a wymaganiami gramatycznymi języka fonicznego danego kraju. W ten sposób w Polsce powstał System Językowo-Migowy. Tyle że kiedy w naszym kraju formowano podstawy SJM, w społeczeństwach zachodnich rozpoczął się odwrót od doktryny oralizmu. Powoli rehabilitowano język migowy i kulturę Głuchych, nadając tej społeczności status mniejszości językowej. W Polsce jednak oralizm nie odszedł całkiem do lamusa i jego elementy wciąż pobrzmiewają w polityce słyszącej większości wobec niesłyszących. Dla Głuchych sztandarowym przykładem doktryny oralizmu jest propagowanie Systemu Językowo-Migowego (jako opartego na języku fonicznym) i deprecjonowanie Polskiego Języka Migowego.

Jak już wcześniej wspomniałam, System powstał, by ułatwić komunikację słyszących z niesłyszącymi, a tym ostatnim umożliwić poznanie języka polskiego. Obecnie SJM stanowi podstawę edukacji językowej w szkołach dla niesłyszących, a także oficjalny „język migowy” mediów. Głusi protestują przeciwko takiemu stanowi rzeczy. Po pierwsze, faworyzowanie w szkolnictwie i sferze publicznej SJM sprawia, że naturalny język migowy, jeśli nawet nie jest usuwany w cień, to na pewno jest „zanieczyszczany” zasadami Systemu (na przykład daktylograficznymi końcówkami wyrazów, których niefleksyjny PJM nie posiada). Tworzy się tzw. hybryda, czyli okaleczony i zmieniony język migowy, taki migany pidgin. I podobnie jak zapożyczenia $z$ obcych języków przekształcają polszczyznę, tak SJM nieubłaganie zmienia strukturę PJM.

Po drugie, System, jako język edukacji, sfery publicznej i mediów w powszechnej świadomości wypiera język migowy. Przeciętny człowiek, widząc w telewizorze migającą osobę, nie zdaje sobie sprawy, że lektor posługuje się sztucznie stworzonym systemem, a nie naturalnym językiem głuchych - dla ogółu społeczeństwa nie istnieje więc coś takiego jak Polski Język Migowy, a o coś czego „nie ma”, trudno się walczy. Wydarzeniem charakterystycznym dla stosunku słyszącej większości do języka migowego jest ustawa, która ma zagwarantować głuchym status mniejszości językowej (obiecał to w swoim exposé premier Donald Tusk ${ }^{34}$ ) — problem polega na tym, że do ustawy jako język mniejszości ma być wpisany SJM, a nie Polski Język Migowy.

Dominacja Systemu i deprecjonowanie PJM zdarza się nie tylko wśród niezorientowanych, ale także wśród osób i instytucji, które powinny być najlepiej poinformowane w sprawach niesłyszących. Według Głuchych, jeśli prowadzone

34 Por. stenogram z drugiego posiedzenia Sejmu RP (23 listopada 2008); http://orka2.sejm. gov.pl/StenoInter6.nsf/0/6372FE4B9619C127C125739D0053E245/\$file/2_a_ksiazka.pdf [11.06. 2008]. 
są jakiekolwiek kursy języka migowego, czy to przez Polski Związek Głuchych, czy inne organizacje, to $z$ dużym prawdopodobieństwem można stwierdzić, że jest to właśnie kurs SJM, a nie PJM ${ }^{35}$. W efekcie kształceni tłumacze języka migowego, którzy mieliby pracować w sądach, urzędach, placówkach dla niesłyszących czy uczelniach wyższych, posługują się nieakceptowanym i nie do końca zrozumiałym dla większości głuchych Systemem. Czyni to ich pracę zupełnie nieprzydatna, bo choć wychowany w kulturze języka migowego Głuchy zapewne w końcu zrozumie tłumacza (bo sam przynajmniej elementy SJM poznał $\mathrm{w}$ szkole ${ }^{36}$ ), to odpowiadając mu nawet hybryda, pozostanie niezrozumiany. Głusi sami przyznają, że System jest sztuczny, nienaturalny, sztywny, nieintuicyjny, pozbawiony tak koniecznej dla zrozumienia niesłyszącego ekspresji ${ }^{37}$.

W odpowiedzi na Niemy Protest na różnych stronach internetowych, blogach i forach ${ }^{38}$ pojawiły się wpisy oskarżające protestujących o przeinaczanie faktów i szerzenie nieprawdziwych informacji. Chciałabym tu poczynić jedno zastrzeżenie. Nie mogę być tego pewna, ale styl i charakter tych wypowiedzi wskazują na to, że ich autorem jest jedna osoba, może dwie, co sprawia wrażenie, iż mamy do czynienia z prywatną kampanią. Sądzę jednak, że warto przyjrzeć się poglądom przez tę osobę/osoby głoszonym, bo stanowi to przeciwwagę dla prokulturowych działań Głuchych. Ponadto warto się zastanowić i na poczet przyszłych badań empirycznych zadać sobie pytanie, ilu jedna lub druga opcja ma zwolenników wśród polskich niesłyszących (a nie tylko polskich niesłyszących internautów).

Podstawowy zarzut, jaki jest formułowany pod adresem Głuchych, głosi, iż nie mają odrębnej kultury, że coś takiego jak kultura Głuchych po prostu nie istnieje. Głusi współdzielą z Polakami historię, tradycję, obyczaje, religię,

35 Por. wypowiedzi w wątku: http://forum.alldeaf.pl/topics439/2647.htm na forum Alldeaf oraz w wątkach http://www.deaf.pl/forum_deaf,topic,7587.msg50067.html\#msg50067 i http://www.deaf.pl/forum_deaf,topic,6257.0.html na forum Deaf.pl [11.06.2008].

36 Tak jak wspomniałam wcześniej, w placówkach edukacyjnych głusi teoretycznie uczeni są SJM, w praktyce jednak poznają tylko niektóre jego zasady, bo nauczyciele — zwłaszcza ci z długim szkolnym stażem - migają hybrydą. Stąd nikła znajomość „czystego” SJM wśród głuchych. Z kolei tłumacze uczeni są w zasadzie tylko „nieskażonego” SJM.

37 Por. wypowiedź internetową: „[...]od dzieciństwa korzystałam z PJM i wcale nie miałam z tym problemu, tak moim zdaniem i uważam że ten język jest o wiele łatwiejszy niż SJM... Dlaczego??? W SJM jest wiele rzeczy które trzeba tak dokładnie przemigać, przeliterować itd...” - http://forum.alldeaf.pl/topics439/3481.htm [11.06.2008] oraz wypowiedź „Migam SJM, migam jak robot, skupiam się na wyrazach, na treści, żeby jakiegoś słowa nie przegapić, już nie wspomnę, że rozmówcy Głuchego dawno już nie ma, który nie ma cierpliwości, a co dopiero chęci zrozumienia, to co migam (na przykład idiomy, zwroty, skróty), i sama się gubię. Migam PJM, umiem swobodnie siebie wyrazić, gram własnym ciałem, pozwalam sobie na ekspresję i nie mam uczucia $z$ wyrzutami sumienia, że "rozmawiamy" wbrew sobie, ja siebie rozumiem a i Głuchy rozmówca mnie zrozumie"; http://www.deaf.pl/ index.php?PHPSESSID =cc343d6a2f3e88ee025e611108073292\&topic =8709.20 [11.06.2008]

38 http://migowy.profeo.pl; http://migowy.i-fora.net; http://migowy.blogspot.com; http:// forum.gazeta.pl/forum $/ 72,2 . \mathrm{html} ? \mathrm{f}=644 \& \mathrm{w}=75950085 \& \mathrm{v}=2 \& \mathrm{~s}=0$, a także pojedyncze wpisy na cytowanych już przeze mnie forach i blogach. 
system polityczny i gospodarczy — w zasadzie więc wszystkie elementy konstytuujące kulturę. Pozostaje tylko odrębność językowa. Czy to jednak wystarczy, by ogłosić kulturową odmienność osób głuchych? Tym bardziej że i co do statusu samego języka nie ma zgody. Na kilku internetowych stronach znalazłam argumenty za tym, że dokonano pewnego przekłamania w nazewnictwie. Otóż to, co uznaje się za Polski Język Migowy, to tak naprawdę nic innego jak Naturalny Język Głuchych, domowe systemy porozumiewania się, niejednolite i w związku z tym nie obejmujące większych społeczności. Jedynym językiem migowym, który można nazwać polskim, jest ten określany mianem Systemu Językowo-Migowego - bo powstał na terenie Polski i powszechnie posługują się nim Polacy. Stąd dyskretna zmiana w nomenklaturze: zamiast PJM i SJM, istnieje NJG i PJM, ale ten ostatni skrót jest rozwijany jako Polski Język Migany.

Zwalczany przez Głuchych System ma także, wedle przeciwników kulturowej odrębności niesłyszących, o wiele więcej zalet niż naturalny język migowy. Po pierwsze, jako odzwierciedlenie polskiego języka fonicznego tak naprawdę dokonuje akulturacji głuchych, pozwalając im w pełni uczestniczyć w piśmiennej kulturze społeczeństwa polskiego. Po drugie, ponieważ System ma swoje źródła w języku fonicznym, oddaje pełne bogactwo języka mówionego, wraz z synonimami, wyrażeniami abstrakcyjnymi i terminologią naukową - czyli te wszystkie pojęcia, które potrzebne są, by dobrze rozumieć współczesny świat, a z których przekazaniem ma kłopoty naturalny język głuchych. Po trzecie, jako jednolity system porozumiewania się umożliwia „rozmowę” osobom z różnych regionów kraju i różnych środowisk. Po czwarte, osobom znającym System łatwo będzie się komunikować z kształconymi w SJM tłumaczami, co oznacza łatwiejsze przejście przez wszystkie biurokratyczne procedury w urzędach, pewniejszą pomoc w szpitalu, szkole, sądzie czy na komisariacie policji.

Najważniejszy jednak zarzut stawiany Głuchym promującym PJM/NJG to tendencja do zamykania niesłyszących w językowym getcie. Przeciwnicy Niemego Protestu zauważają, że Głuchy „mówiący” tylko PJM jest skazany na kontakty wyłącznie $z$ innymi Głuchymi. Wszyscy inni migający - tłumacze, nauczyciele, terapeuci, słyszący - znają przede wszystkim System. Po drugie, upieranie się przy języku migowym i lekceważenie języka polskiego (chociażby zapośredniczonego przez System) sprawia, że Głuchy zostanie wykluczony w zasadzie $z$ uczestniczenia w życiu kulturowym społeczeństwa. Jego zasób słów $z$ fonicznej polszczyzny okaże się zdecydowanie za mały, by był w stanie czytać ze zrozumieniem książki, gazety, wpisy na stronach internetowych; by zdał maturę i poszedł na studia. Dla Głuchego tajemnicą pozostanie bogactwo synonimów czy terminologia naukowa, których to nie da się dobrze przetłumaczyć na język migowy. W efekcie głuchym pozostaną szkoły zawodowe i nisko płatne zajęcia, co tylko pogłębi ich izolację i obniży status społeczny. Pod tym względem oparty na polskim języku fonicznym System, jako podstawa kształcenia i kontaktów w sferze publicznej, jest zdecydowanie lepszy. 
Głusi ripostowali, że nikt z nich tak naprawdę nie chce eliminacji SJM. Dostrzegają użyteczność Systemu w porozumiewaniu się ze Słyszącymi, a także z tymi głuchymi, którzy znają lepiej SJM od PJM (na przykład dzieci rodziców słyszących kształcone w szkołach dla niesłyszących, gdzie jako ,język wykładowy" obowiązuje System). Z kolei w edukacji dwujęzycznej, gdy dziecko najpierw poznaje język migowy, a potem pisany język polski, SJM może stanowić narzędzie ułatwiające „przełożenie” jednego języka na drugi ${ }^{39}$. Ponadto sami niesłyszący, których uczono w szkole migać Systemem, później mają problemy z rozpoznawaniem, jakie znaki i zasady pochodzą z PJM, a jakie z SJM. W efekcie większość $z$ nich miga hybrydą, nawet nie zdając sobie sprawy ${ }^{40}$.

Głusi kulturowo ubolewają, że wśród niesłyszących jest niska świadomość językowa i wielu z nich nie zdaje sobie sprawy z różnic między językiem migowym a Systemem, $z$ tego, że PJM może być w jakikolwiek sposób zagrożony. Wydaje się więc, że występuje pewna gradacja zaangażowania w kulturę i język Głuchych: najsłabiej wykształceni, którzy nie ukończyli żadnej szkoły, migają w PJM, wyniesionym z domu rodzinnego; osoby, które były uczniami placówek dla niesłyszących i nie mają świadomości językowej, migają przede wszystkim w SJM lub hybrydą z przewagą SJM; osoby wykształcone i świadome językowo znają System, ale starają się migać PJM. Zmiany w edukacji mają sprawić, że język migowy nie byłby tylko językiem domowym i językiem głuchych elit, ale „zapełniłby" także lukę między domem a grupami zaangażowanych w obronę języka Głuchych - lukę, w której mieści się znaczna część społeczności niesłyszących. Powszechność PJM w środowisku głuchych ułatwi zaś kampanię informującą słyszących, że głusi mają swój język i nie jest to gestowy odpowiednik fonicznego języka polskiego.

Z kolei według przeciwników Niemego Protestu propagowanie PJM jako języka kształcenia głuchych grozi tym, że osoby, które skończą swoją edukację na niskim szczeblu, będą znały tylko ograniczony (według przeciwników NP) kod języka migowego - Naturalnego Języka Głuchych. $Z$ powodu rezygnacji z nauki Systemu foniczny język polski pozostanie dla takich osób językiem obcym, nierozpoznanym i niezrozumiałym. Natomiast lepiej wykształceni i świadomi różnic językowych nie dość, że będą w stanie operować PJM/NJG, to jeszcze swobodnie skorzystają z opartego na polskim języku fonicznym Systemu. W ten sposób łatwiej będzie im się odnaleźć w rzeczywistości słyszących, zdobyć wiedzę we współczesnym świecie. Propagowanie PJM/NJG nie tylko nie przełamie zatem barier między słyszącymi i niesłyszącymi, ale jeszcze umocni mury getta głuchych. Stąd dość mocne słowa przeciwników Niemego Protestu,

39 Por. wypowiedź: „Jeśli oczekuje się nauczania dwujęzycznego, to SJM powinien być ujmowany jako normalny system wspomagający naukę języka polskiego. Tolerancja na styku SJM-PJM oznacza, że tolerancja jest wyrażana i Głuchym, i dla PJM tak samo jak dla głuchych i dla SJM"; http://www.deaf.pl/forum_deaf,topic,9080.0.html [11.06.2008].

40 Por. wątek: http://www.deaf.pl/forum_deaf,topic,9080.0.html [11.06.2008]. 
zarzucających Głuchym i Instytutowi Polskiego Języka Migowego działalność szkodliwą dla społeczności niesłyszących, a wręcz faszystowską wobec Słyszaków i głuchych zwolenników SJM ${ }^{41}$. W tym miejscu spór o język, o kulturową tożsamość, staje się także walką o samoświadomość niesłyszących, o - patetycznie rzecz ujmując — władzę nad umysłami i sercami polskich g/Głuchych.

\section{PODSUMOWANIE}

Przyznanie językowi migowemu statusu pełnoprawnego języka ludzkiego, a społeczności Głuchych miana mniejszości językowej wbrew pozorom nie jest tylko kwestią zmian w społecznej świadomości i wyzwaniem dla polityków, urzędników czy pedagogów. Ta decyzja ma o wiele dalej idące konsekwencje, także dla nauk społecznych. Po pierwsze, zmusza do reinterpretacji pojęcia „języka”, które zadomowiło się w socjologicznej i antropologicznej tradycji. Przyjęcie, iż system gestów również może stanowić język, sprawia, że nie da się dłużej utrzymać definicji języka ludzkiego jako systemu symboli dźwiękowych. Co za tym idzie, ostatni bastion człowieczeństwa według Lévi-Straussa, czyli mowa, zostaje poważnie naruszony. Wydaje się, że rozwiązaniem mogłoby być inne rozłożenie akcentów i uznanie, że to nie foniczność jest główną cechą języka ludzkiego, ale świadome i rozmyślne tworzenie i posługiwanie się przez ludzi systemem symboli — zarówno dźwiękowych, jak i gestowych.

Co za tym idzie, teoretycznego uporządkowania wymaga cała sfera zjawisk językowych. Na nowo należy nakreślić relacje między językiem, mową, gestami i pismem. Jednym z problemów wartych rozważenia jest kwestia trwałości i uniezależniania od kontekstu poszczególnych sposobów porozumiewania się. W ujęciu klasycznym najbardziej nietrwały i związany z sytuacją użycia jest gest. Mowa wydaje się być bardziej przestrzenna, bo komunikowanie się za jej pomocą nie wymaga bezpośredniego kontaktu wzrokowego. Wygłoszony zaś za jej pomocą komunikat jest $z$ jednej strony ulotny (bo wypowiedziane słowa są niematerialne i bez zarejestrowania ich przy użyciu urządzeń elektronicznych, istnieją tak długo jak ślad po nich w pamięci ludzkiej), z drugiej strony trwały (bo odzwierciedla strukturę języka, co uniezależnia go od kontekstu wypowiedzenia słów). Pismo z kolei nie tylko nie wymaga bezpośredniej styczności nadawcy i odbiorcy przekazu, ale umożliwia „przechowywanie” informacji

41 Por. fragment wpisu na blogu: „Oznaka Rasizmu jest mówienie, że tylko My migamy JĘZYKIEM. (Wyższość rasy migaczy nad druga) Stowarzyszenie IPJM i organizacja ONSI wyśmiewa się, szydzi i kpi z innej grupy migającej, że tamci nie migają językiem lub go nawet nie mają. Rasizm jak również oznaki Faszyzmu"; http://migowy.blogspot.com/2008/04/jezykowy-rasizm-gluchychproblemem.html [11.06.2008] oraz inne wpisy na tym blogu, a także: http://migowy.profeo.pl/ blog/view/4357/Gluchy-nie-chce-PJM-Gluchy-migaj-i-mow-po-Polsku-W-Getcie-Gluchym-migajNJM.html [11.06.2008]; http://img75.imageshack.us/img75/409/forumfaszyzmix7.gif [11.06. 2008]; oraz drugą połowę dyskusji forum.gazeta.pl: http://forum.gazeta.pl/forum/72,2.html?f= $644 \& \mathrm{w}=75950085 \& \mathrm{v}=2 \& \mathrm{~s}=0[11.06 .2008]$. 
przez dłuższy czas w formie niezmienionej ułomnością pamięci ludzkiej. Pismo niejako „konserwuje” komunikat, udostępniając go wielu odbiorcom w dowolnym czasie i miejscu. Uznanie języka migowego za pełnoprawny język ludzki zmienia status gestów. W tym ujęciu pod względem trwałości, rozumianej jako odzwierciedlenie struktury języka i niekontekstowość komunikatu, informacja przekazywana poprzez gesty nie różni się od tej realizowanej za pomocą mowy. Kontinuum uzależnienia treści komunikatu od sytuacji jego wytworzenia klasycznie ujmowane: od gestu przez mowę do pisma - w przypadku języka migowego zostaje unieważnione.

Po drugie, zrównanie $\mathrm{w}$ prawach języków fonicznego i migowego zmusza do zastanowienia nad teoretycznymi podstawami nauk społecznych, $\mathrm{w}$ tym socjologii. Czy nie jest tak, że socjologiczne patrzenie na rzeczywistość, interpretowanie zachowań ludzkich, analizy struktury społecznej, których punktem centralnym jest język, zostały „skażone” fonicznością? W jakim stopniu koncepcje etnometodologii czy symbolicznego interakcjonizmu dadzą się utrzymać, jeśli przyjmiemy, że użycie języka to nie tylko mowa, ale i gesty? Czy wówczas wypracowane zasady, znalezione wzory, odkryte rytuały nadal funkcjonują? Innymi słowy, w jakim stopniu teoria socjologiczna jest odporna na wszelkie zmiany w definicji języka, a w jakim założono w niej a priori, że jeśli cokolwiek dokonuje się poprzez język, to na pewno w aktach mowy? Zdefiniowanie języka jako systemu symboli dźwiękowych albo gestowych staje się więc swoistym testem dla uniwersalności socjologicznych teorii.

Po trzecie, sytuacja języka migowego i postulat budowania na jego bazie tożsamości kulturowej zmusza do przyjrzenia się bliżej właśnie kwestii tożsamości kulturowej. Odpowiedzi domaga się następujące pytanie: czy o odmienności kulturowej może decydować tylko i wyłącznie odrębność językowa? Wyrażenie zgody wymagałoby uznania jednocześnie, że to język stanowi rdzeń kultury, skoro odarcie jej z wszelkich pozajęzykowych lub językowo zapośredniczonych elementów (tradycja, zwyczaje, wierzenia, kultura materialna, prawo czy system gospodarczy) i tak daje prawo do mówienia o kulturze i wyodrębniania kulturowo różnych grup społecznych. Idąc dalej tym tropem, o kulturowo zdeterminowanej dychotomii swój-obcy można by orzekać zawsze w przypadku językowo odmiennych społeczności. Co więcej, zniknięcie danego języka oznaczałaby unieważnienie kulturowej odrębności grupy społecznej do tej pory się nim posługującej. Ujmując rzecz metaforycznie: śmierć języka równa jest wówczas śmierci kultury.

\section{BIBLIOGRAFIA}

Aitchison Jean, 2002, Ziarna mowy: początki i rozwój języka, tłum. Magdalena Sykurska-Derwojed, Państwowy Instytut Wydawniczy, Warszawa.

Antas Jolanta, 2006, Gesty — obrazy pojęć i schematy myśli, w: Ikoniczność znaku. Stowo. Przedmiot. Obraz. Gest, Elżbieta Tabakowska (red.), Universitas, Kraków. 
Derrida Jacques, 2005, Ten ruch batuty, w: Antropologia widowisk. Zagadnienia $i$ wybór tekstów, oprac. Agata Chałupnik i in., Leszek Kolankiewicz (red.), Wydawnictwo Uniwersytetu Warszawskiego, Warszawa.

Fodor Jerry A., 2001, Eksperci od wiązów: język myśleński i jego semantyka, tłum. Marcin Gokieli, Aletheia, Warszawa.

Giddens Anthony, 2006, Socjologia, tłum. Alina Szulżycka, Wydawnictwo Naukowe PWN, Warszawa.

Głowiński Michał (red.), 1980, Jezzyk i społeczeństwo, Czytelnik, Warszawa.

Kłoskowska Antonina, 2005, Kultury narodowe u korzeni, Wydawnictwo Naukowe PWN, Warszawa.

Kłoskowska Antonina, 2007, Socjologia kultury, Wydawnictwo Naukowe PWN, Warszawa.

Leakey Richard, 2003, Sztuka mówienia, w: Antropologia słowa. Zagadnienia i wybór tekstów, oprac. Grzegorz Godlewski (red.), Andrzej Mencwel, Roch Sulima, Wydawnictwo Uniwersytetu Warszawskiego, Warszawa.

Lévi-Strauss Claude, 2003, Kultura $i$ jezzyk, w: Antropologia stowa. Zagadnienia $i$ wybór tekstów, oprac. Grzegorz Godlewski, Andrzej Mencwel, Roch Sulima, Wydawnictwo Uniwersytetu Warszawskiego, Warszawa.

Piotrowski Andrzej, Ziółkowski Marek, 1976, Zróżnicowanie językowe a struktura społeczna, Państwowe Wydawnictwo Naukowe, Warszawa.

Riesman David, 2003, Tradycja oralna a stowo pisane, w: Antropologia stowa. Zagadnienia $i$ wybór tekstów, oprac. Grzegorz Godlewski, Andrzej Mencwel, Roch Sulima, Wydawnictwo Uniwersytetu Warszawskiego, Warszawa.

Rousseau Jean Jacques, 1956, Trzy rozprawy z filozofi społecznej, tłum. Henryk Elzenberg, Państwowe Wydawnictwo Naukowe, Warszawa.

Rousseau Jean Jacques, 2001, Szkic o pochodzeniu języków, tłum. Bogdan Banasiak, Aureus, Kraków.

Sapir Edward, 1978, Kultura, jezzyk, osobowość. Wybrane eseje, tłum. Barbara Stanosz, Państwowy Instytut Wydawniczy, Warszawa.

Sapir Edward, 2003, Jezyk, w: Antropologia słowa. Zagadnienia i wybór tekstów, oprac. Grzegorz Godlewski, Andrzej Mencwel, Roch Sulima, Wydawnictwo Uniwersytetu Warszawskiego, Warszawa.

Sejm, 2008, stenogram z drugiego posiedzenia Sejmu RP (23 listopada 2008), http:// orka2.sejm.gov.pl/StenoInter6.nsf/0/6372FE4B9619C127C125739D0053E245/\$ file/2_a_ksiazka.pdf [11.06.2008]

Szczepankowski Bogdan, 1997, Język migowy jako środek komunikacji, „Problemy Rehabilitacji Społecznej i Zawodowej”, nr 2; http://www.glusi.pl/publikacje/publikacje_7. html [11.06.2008].

Szczepankowski Bogdan, 2000, Czy język migowy jest mowa ciała?, „Świat Ciszy”, nr 1; http://www.pzg.org.pl/sc/sc_jm_cialo.asp [11.06.2008].

Sztompka Piotr, 2004, Socjologia. Analiza spoteczeństwa, Znak, Kraków.

Sztompka Piotr, 2006, Socjologia wizualna. Fotografia jako metoda badawcza, Wydawnictwo Naukowe PWN, Warszawa.

Świdziński Marek, 2003, Po głuchoniemsku, „Charaktery”, nr 7.

Tomaszewski Piotr, 2007, Podstawowe dane lingwistyczne $i$ socjolingwistyczne na temat naturalnego jezzyka migowego, „Studia nad Językiem Migowym”, nr 1; http://www.ipjm.pl/ index.php?lang = pl\&item $=$ pubs [11.06.2008]. 
Turner Ralph H., 2006, Koncepcja siebie w interakcji spotecznej, w: Wspótczesne teorie socjologiczne, wybór i oprac. Aleksandra Jasińska-Kania, Lech M. Nijakowski, Jerzy Szacki, Marek Ziółkowski, Scholar, Warszawa.

Włodarski Artur, 2002, Jest doskonaty, „Gazeta Wyborcza”, 24 kwietnia.

Woźniak Olga, 2008, Gtusi swój jezzyk mają, „Gazeta Wyborcza”, 5 kwietnia.

Ziółkowski Marek, 1981, Znaczenie — interakcja - rozumienie, Państwowe Wydawnictwo Naukowe, Warszawa.

Ziółkowski Marek, 1998, Język i komunikowanie, w: Encyklopedia socjologii, t. 1, Oficyna Naukowa, Warszawa.

Strony internetowe

http://www.migowy.pl

http://www.glusi.pl

http://www.signwriting.com

http://glusi.blox.pl

http://www.deaf.pl

http://forum.alldeaf.pl

http://wiadomosci.onsi.eu

http://migowy.profeo.pl

http://migowy.i-fora.net

http://migowy.blogspot.com

http://migofil.blogspot.com

http://pjm.interpsi.ok.pl

http://forum.gazeta.pl/forum/72,2.html?f $=644 \& \mathrm{w}=75950085 \& \mathrm{v}=2 \& \mathrm{~s}=0$

\section{THE DEAF AND SIGN LANGUAGE - A DISPUTE ABOUT LANGUAGE AND CULTURE}

Summary

The article tries to describe phenomena that have so far largely not captured the attention of the Polish social sciences, that is the process of crystallization and manifestation of the cultural identity of the deaf. The controversies presented here concern mainly two questions. The first is whether the sign (visual-spatial) language may be treated on a par with a phonic one as another type of human language. Secondly, whether on the basis of this linguistic differentiation one can speak of the cultural and linguistic identity of the deaf. In such a case the destruction of the sense of hearing would not be treated as a physical disability, but as a characteristic of cultural otherness. Moreover, one can be culturally Deaf even if one can hear - the factors that constitute the minority Deaf Culture are above all: the use of sign language, the recognition of its primacy over the artificial systems of sign language and a phonic language as well as the protection of the cultural heritage of the Deaf in a society capable of audition where the Deaf are discriminated against and "discultured" (for example by the system of education or the imperative of curing deafness by cochlear implants). 
Key words/słowa kluczowe

cultural identity / tożsamość kulturowa; linguistic minority / mniejszość językowa; sign language / język migowy; Deaf Culture / Kultura Gluchych; oralism / oralizm; audism / audyzm 